\title{
Landed Traders, Trading Agriculturalists? Land in the Economy of the Italian Diaspora in the Greek East*
}

\author{
LISA PILAR EBERLE AND ENORA LE QUÉRÉ
}

\author{
ABSTRACT
}

This paper revises current understandings of the role of land in the economy of the Italian diaspora in the Greek East in the second and first centuries B.C., arguing that these Italians owned more land than has previously been assumed and that many of these Italian landowners practised a highly commercialized form of agriculture that focused on highend products. This strategy shaped what empire meant both locally and in Italy and Rome, where the products they marketed fed into the ongoing consumer revolutions of the time. After discussing the evidence for the extent of Italian landholdings and examining their exploitation in three case studies, we conclude by reflecting on the longterm history of such landholdings in the provinces and the implications for our understanding of Roman imperialism more generally.

Keywords: Italian diaspora; Greek East; Roman economy; landownership and exploitation; impact of the Roman Empire; high-end goods; historical archaeology

\section{INTRODUCTION}

Scholars have been discussing the economic profile of the many Italians who went to live in the Roman provinces during the second and first centuries B.c. for about a hundred years. The details of these discussions vary but they show a marked tendency to downplay the rôle of landholding, preferring to cast these Italians as bankers and traders, at times connected with Roman military activity. While some fail to mention land altogether or emphasize the limited extent of Italian holdings, others see land as unconnected with and incidental to the Italians' otherwise commercial interests, acquired either for social prestige or as a result of debtors defaulting. These ideas about the economic profile of the Italian diaspora are crucial for how historians imagine that this diaspora shaped Roman imperialism and its local impact. ${ }^{1}$

\footnotetext{
* This article has its origin in a chance meeting at the École française d'Athènes in 20I3, where we realized that we could combine our research to make a much broader point. In addition to the EfA, who hosted both of us at the time, and the American School for Classical Studies in Athens, who let us consult the papers of the late Virginia Grace in their archives, we thank Jean-Sébastien Balzat, Roland Étienne, Carlos Noreña, Nicholas Purcell and the audience at the Roman Discussion Forum in Oxford for their valuable feedback on our piece in the final stages of writing as well as the three anonymous reviewers for $J R S$, who made helpful suggestions for how to shorten the argument.

1 Hatzfeld I9 I9 remains foundational. No study we cite here questions banking or trading. Connection to Roman military activity: e.g. Purcell 2005: 9I-2; Thonemann 20I0: I72-3. No mention of land: e.g. Gsell I9I4: 69-73; Delplace I977: 240-2. Italian landholding as 'occasional': e.g. Magie I950: 163-4, I053; Rousset 2004: 371-2.
} 
As with many aspects of our understanding of Rome's imperial diaspora, this downplaying of land in the diaspora's economy has no linear historiography. Instead, three separate factors have contributed to it, which can all now be called into question. First, while the Latin negotiatores, a word often found in relation to members of the diaspora, has commonly been thought to connote bankers and traders, there is now an ever-growing set of arguments that in the late Republic the word had a very broad scope, including landowners. ${ }^{2}$ Second, in the Greek East the paradigmatic status of Delos has contributed to seeing diasporic Italians as bankers and traders. ${ }^{3}$ Such a status, however, cannot be assumed, it must be proven; anything else would simply mean being seduced by the wealth of evidence from the site. What is more, Italians on Delos did demonstrably own land there. ${ }^{4}$ Lastly, Moses Finley's insistence on the incompatibility of landowning on the one hand and commerce and profit-seeking on the other, has also played a part in sidelining the rôle of land in accounts of the economy of the Italian diaspora, a group of people thought to be mainly concerned with lucrum; ${ }^{5}$ hence the suggestions that members of the diaspora purchased land to gain social prestige or that social élites would have turned over their land to tenants, receiving rents from them. ${ }^{6}$ While many aspects of Finley's argument have come under attack, the static nature of the model he formulated has turned out to be its weakest aspect. ${ }^{7}$ Today the greatly variable nature of the exploitation of natural resources in Greco-Roman antiquity is well-recognized. ${ }^{8}$ Together these three arguments have clearly undone the assumptions on which the prevalent interpretation of the rôle of land in the economic profile of the Italians was based. Indeed, recently scholars have begun to imagine a possible 'interdependence of their "landed" and "commercial" interests'. 9 The place of land in the economy of the diaspora thus now appears as a research problem waiting to be investigated, and this is the question that we propose to tackle in this article. ${ }^{10}$

Focusing on the Greek East, where evidence is most plentiful, we argue that more Italians owned agricultural and natural resources in the provinces than has previously been recognized, that these Italians were particularly interested in producing high-end goods, and that they were involved in commercializing their products, exporting them to, among other places, markets in Rome and Italy. These Italians thus played a crucial

Land as afterthought, unconnected to commercial interests: e.g. Frank I933: 387-92; Alcock I989: 8; I993: 74-6; Rizakis 2002: I23. Land mainly resulting from defaulting debtors: e.g. Brunt I97I: 2I3-I4; I988: I69-72; Cassola I970-7I: 307, 3 I0-II; Sartre I995: I 54, 277. Land acquired for social prestige: e.g. Wilson I966: I60; Brunt I988: I63; MacMullen 2000: 5; Zoumbaki 20I4b: I92. For these Italians as a 'diaspora' see Purcell 2005: 85 .

2 Nicolet I966: 358-9; Wilson I966: 4-6; Brunt I988: I68-9; Feuvrier-Prévotat I989: 38 I; Verboven 2007; Tran 20I4; Eberle forthcoming.

3 Most recently, Müller and Hasenohr 2002. Étienne 2002: 3, 6-7 calls Delos a 'laboratoire' for developing questions about the diaspora. Müller 2002: 97 and Rizakis 2002: IIO, I23 dismiss evidence for Italian landholding in Achaea and Macedon as minimal.

4 ID I4I6 B, II I, 1l. 5-I3; ID I4I7 B, II I, ll. 94-7, I 26-9 with Roussel [I9I6]I987: I 5 I, I 57 (Italians leasing properties of Apollo); Cic., Att. 9.9.4 with Bruneau I988: 569-73 (Atticus' properties on Delos).

5 Finley I98I: I 88, I94; I999: 4I-3. On the diaspora and lucrum see Prop. 3.20.I-4; Cic., Quinct. 3.II-I3; Hor., Carm. 4.I2 with Thonemann 20II: 252. Errington I988: I43 takes up these ancient perceptions in his analysis.

6 e.g. Wilson I966: I60; Alcock I989: 8; I993: 74-6; Zoumbaki 20I4b: I92. But see now Alcock 2007: 69I, which we discuss below. The one scholar who has no problem with landowners among the diaspora is Hatzfeld I9I9: 212-33, who calls them 'industriels', a designation that together with other passages in his works (e.g. Hatzfeld I945: I34-5) places him on the modernist side of the early twentieth-century debate about the ancient economy.

7 Lanauro 2016: 247.

8 e.g. Halstead I987; Kay 20I4: I33-4I; most influentially Horden and Purcell 2000.

9 The quote is from Alcock 2007: 69I (her quotation marks). See also Zoumbaki 20I 2: 82 and 20I3: 56 who suggests that Italians 'invest in land' for 'social and economic reasons'.

10 For recent interest in Roman landholding see Erdkamp et al. 2015 ; Lerouxel and Pont 2016. 
rôle in defining what empire meant, not only in the communities in which they owned their agricultural and natural resources but also in the metropolitan centre, where their products contributed to a set of consumer revolutions. ${ }^{11}$ As such, this paper is written with the conviction that just as economic history cannot be understood in isolation from cultural, social and political history, it should not limit its investigation to the questions of modern economics either.

Our argumentation combines breadth and depth. At its heart lie an index of all known instances of Italians owning agricultural and natural resources in the Greek East during the second and first centuries B.C. and three case studies of Italian properties and their exploitation in Epirus, Cos and Chios, and Melos, which explore Italian strategies and behaviour in different ecological contexts. The case studies combine literary, epigraphical and archaeological evidence. While literary and epigraphical documents, which have informed interpretations of landownership among Italians in the provinces so far, show that Italians owned some natural resources in the provinces, they remain silent on what Italians did with them. This is where archaeology, in various guises, enters our argumentation, revealing itself yet again as an invaluable source of insight for thinking about economic life in the ancient world. ${ }^{12}$

\section{THE EXTENT OF ITALIAN LANDOWNERSHIP IN THE GREEK EAST: SPATIAL, TEMPORAL AND} SOCIETAL CONSIDERATIONS

The incontrovertible evidence for Italian landownership in the Greek East down to the end of the first century B.C. looks as follows. ${ }^{13}$ We know twenty-two individual landowners in total, all of whom are attested in the first century в.c. (Table I). Half of them are otherwise unknown, and the other half includes a freedman (Gaius Curtius Mithres), three equestrians (Titus Pomponius Atticus, Lucius Cossinius and Marcus Feridius), an exiled senator (Gaius Antonius), the son of an exiled senator (Appuleius Decianus), a praetor (Lucius Flavius), and two members of the imperial family (Agrippa and Livia). ${ }^{14}$

We also have attestations of anonymous groups of Italian landowners in four different places and three more examples where groups of Italians in Greek cities are called

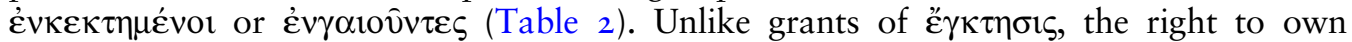
land in Greek cities, to individuals, which might just be part of a standard package of privileges that the city in question gave out, the choice to describe a local group of Italians as having this right indicates that at least some of the men so designated also had an interest in making use of it. ${ }^{15}$

Based on these two sets of evidence, we know of Italian landownership in twenty different places in the first century B.C.: in Epirus (Buthrotum) and on the Ionian islands (Kephallenia); in Macedon (Beroia) and the Peloponnese (Elis, Megalopolis and Messene); on both sides of the Hellespont (Parium and the Thracian Chersonese); on islands in the Aegean (Chios, Cos and Delos); in Aeolis (Cyme and Temnos), Lydia (Apollonis and Thyateira), Ionia (Colophon) and Caria (Alabanda); and in Pontus, Asia

11 On 'consumer revolution(s)' in Italy see Wallace-Hadrill 2008: 3 I 5-440, especially 346.

12 On the importance of archaeological data for a reappraisal of the Roman economy in the Greek East, see e.g. Greene I986; 2006; Alcock 2007: 67I-4; Étienne et al. 2014: 307-7I.

13 We adopt a minimalist approach to the evidence, basing this section only on unquestionable attestations of Italian landownership. For a maximalist approach to (senatorial) landownership, including the provinces, see tables I and II in Shatzman 1975. We do not discuss ager publicus in the Greek East - for which see now Brélaz 20I6: 76, 79, 82 - since locals could exploit it as well.

14 For the interpretation concerning Livia's estates see Hermann I959: I4; Mitchell I993: I6I-2.

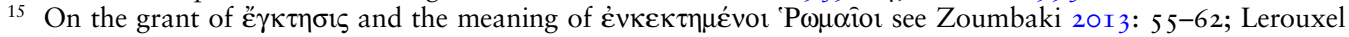
and Pont 20I6: 9-10, n. 2. 
TABLE I Index of individual Italian landowners in the Greek East in the Late Republic (alphabetical order)

\begin{tabular}{|c|c|c|c|c|}
\hline & Name & LOCATION & DATE & REFERENCE \\
\hline $\mathbf{I}$ & G. Antonius & Kephallenia & middle of the first century в.с. & Strabo I0.2.13 \\
\hline 2 & $\begin{array}{l}\text { G. Appuleius } \\
\text { Decianus }\end{array}$ & Temnos and Apollonis & 59 в.С. & Cic., Flac. $5 \mathrm{I}$ and $70-80$ \\
\hline 3 & $\begin{array}{r}\text { T. Arminius } \\
\text { Tauriscus }\end{array}$ & Megalopolis & Augustan age & $\begin{array}{l}\text { IG V.2, } 456 \text { [CIL III.I, 496], ll. 6-8, } \\
\text { with SEG I 5, } 233\end{array}$ \\
\hline 4 & Q. Aufidus Sp. f. & Messene & first century B.C./first century A.D. & $\begin{array}{l}I G \text { V.I, I } 434, \text { ll. 7-9, with } S E G \text { I I, } \\
\text { I035 }\end{array}$ \\
\hline 5 & D. Caecilius M. f. & Messene & first century в.С./first century A.D. & $\begin{array}{l}I G \text { V.I, I } 434,11.3-4 \text {, with } S E G \text { I I, } \\
\text { I035 }\end{array}$ \\
\hline 6 & Caerellia & Asia & 63 в.С. & Cic., Fam. 13.72 \\
\hline 7 & Cluvius & Alabanda & $5 \mathrm{I} / 50$ B.C. & Cic., Fam. I3.56 \\
\hline 8 & L. Cossinius & Epirus & middle of the first century в.с. & $\begin{array}{l}\text { Varro, Rust. 2.IO.I I, with Cic., } \\
\text { Fam. I } 3.23\end{array}$ \\
\hline 9 & G. Curtius Mithres & Colophon & 46 в.с. & Cic., Fam. I3.69 \\
\hline Io & G. Eventius & Messene & first century B.C./first century A.D. & $\begin{array}{l}I G \text { V.I, I } 434,1.2 \text {, with } S E G \text { I I, } \\
\text { I035 }\end{array}$ \\
\hline I I & M. Feridius & Cilicia & 5 I в.с. & Cic., Fam. 8.9.4 \\
\hline $\mathbf{I} 2$ & L. Flavius & Apollonis & 57 в.С. & Cic., $Q$ fr. г.2.Iо \\
\hline $\mathbf{I} 3$ & $\begin{array}{l}\text { L. Genucilius } \\
\text { Curvus }\end{array}$ & Parium & $5 \mathrm{I} / 5 \circ$ B.С. & Cic., Fam. I 3.53 \\
\hline I4 & D. Iulius & Messene & first century в.С./first century A.D. & $\begin{array}{l}I G \text { V.I, I } 434,1.5 \text {, with } S E G \text { I I, } \\
\text { I035 }\end{array}$ \\
\hline I5 & Livia Augusta & Thyateira & $\begin{array}{l}\text { Augustan age, but inscriptions from the late } \\
\text { second/early third century A.D. }\end{array}$ & TAM V.2, 9I 3 and 935 \\
\hline
\end{tabular}


Table I Continued

\begin{tabular}{|c|c|c|c|c|}
\hline & NAME & LOCATION & DATE & REFERENCE \\
\hline 16 & Maeculonius & Cyme & 59 в.с. & Cic., Flac. 46 \\
\hline I7 & Nemerius & Messene & first century в.с. & $I G$ V.I, I $433,1.26$ \\
\hline \multirow[t]{3}{*}{19} & T. Pomponius & Epirus & middle of the first century в.с. & Nep., Att. I4.3; Varro, Rust. 2.Iо.I I \\
\hline & & Buthrotum & 67 в.с. & Cic., Att. I.5.7, with Att. 2.6.2 \\
\hline & & Delos & 49 в.с. & $\begin{array}{l}\text { Cic., Att. 9.9.4, with Bruneau I988: } \\
570-3\end{array}$ \\
\hline 20 & P. Septimius & Asia & 59 в.с. & Cic., Flac. 88 \\
\hline $2 \mathrm{I}$ & $\begin{array}{l}\text { L. Vaccius Labeo } \\
\text { L. f. }\end{array}$ & Cyme & Augustan age & $\begin{array}{l}\text { IKyme I9, ll. 39-4I, with SEG } 27 \text {, } \\
\text { 79I }\end{array}$ \\
\hline
\end{tabular}


TABLE 2 Index of anonymous groups of Italian landowners in the Greek East in the Late Republic (chronological order)

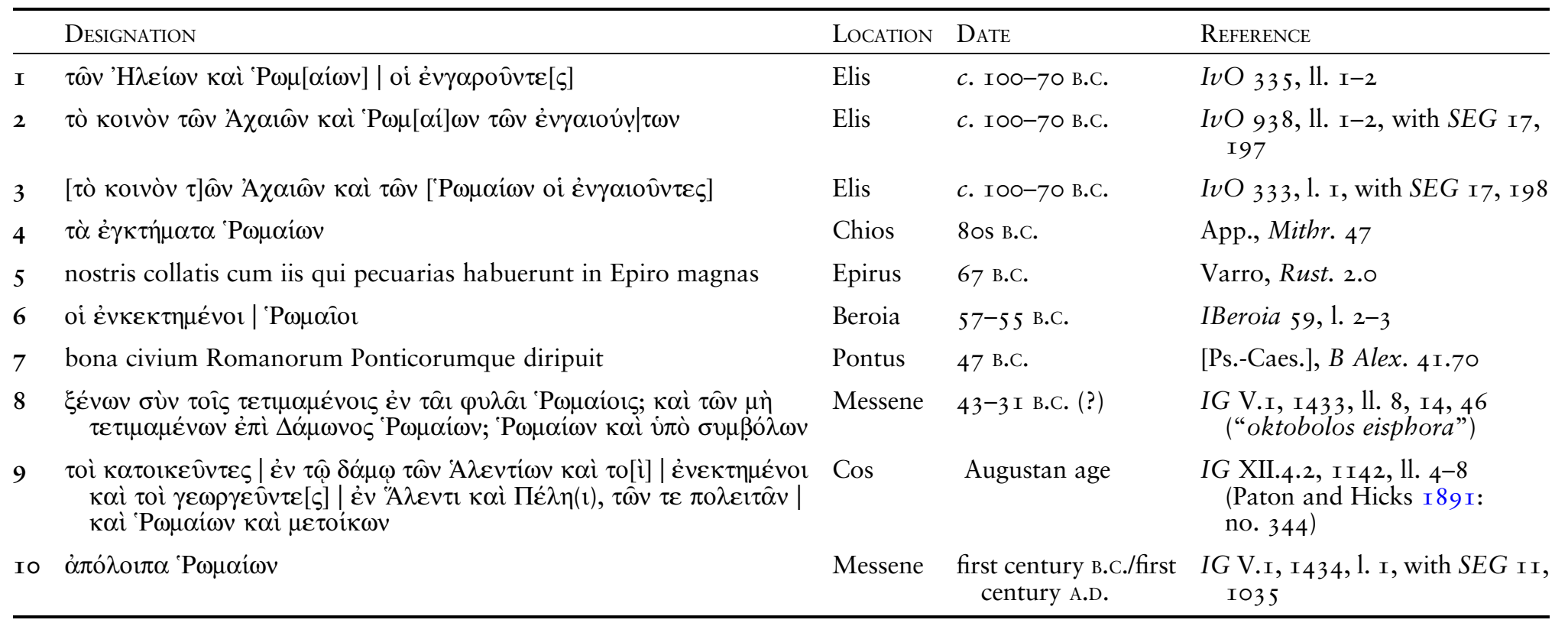


and Cilicia (precise locations unknown) (Fig. I). ${ }^{16}$ There is no reason to think that this evidence is representative of Italian landownership in the Greek East as regards time, place or social make-up. Instead, we want to see it as the arbitrary tip of an iceberg, the precise dimensions of which under the water are to a certain extent always going to remain unknown. Exploring what we can and cannot say about these dimensions is the subject of this section.

All of our evidence for Italian landownership in the provinces is 'unintentional'. ${ }^{17}$ There is no ancient documentation that sets out to register and chronicle it. Instead, we learn about it through occasional mentions in a variety of sources. There are references in ancient literary accounts, such as when Appian relates the conflict between Mithridates and the Chians over how the landholdings of the Italians who had fled to the city should now be taxed. ${ }^{18}$ Greek inscriptions also sometimes mention Italians as landowners. ${ }^{19}$ The Messenian documents concerning the levy of a one-per-cent tax on the property of all citizens and residents, including Italians, are a case in point. ${ }^{20}$ However, about half of the known instances of Italian landownership in the Greek East stem from Cicero's writings between 68 and 46 B.C., above all from the letters of recommendation that he wrote for members of the Italian diaspora introducing them to the incoming governors of the province in which their estates were located. ${ }^{21}$ In light of the prominence of Cicero's writings among the evidence for Italian landownership and the relatively short period of time from which they stem, any attempt to assess the history and chronology of Italian landownership in the Greek East will have to look beyond the sources we have gathered here. As regards the social composition and origin of Italian landowners, the possible bias that results from the dominance of Cicero's writings needs to be borne in mind but these writings also present otherwise unavailable avenues for assessing the problem. Before discussing these two issues, however, we turn to the geographical extent of Italian landownership in the Greek East, the problem to which the data we gathered speak best.

Given the chronological distribution of our evidence, the map we present (Fig. I) can be taken as a rough snapshot of the situation in the middle of the first century B.c. Though it might seem obvious, it is still worth noting: given the unintentional nature of our evidence, the absence of a dot does not mean that Italians did not own land there. In fact, there is plenty of circumstantial archaeological evidence that makes Italian landownership in various other places rather likely. We discuss one such instance in our case study of Melos, which is notably unmarked on the map. Adam Lindhagen also makes a convincing case for Italian landownership in Narona, the much neglected Roman emporion on the Illyrian coast, ${ }^{22}$ and Sophia Zoumbaki has inferred the existence of an Italian estate near Lake Trichonion in Aetolia based on the findspot of a late second-century B.C. Latin funerary inscription of a liberta - an approach that is often used to track Roman landownership in Anatolia during the Principate. ${ }^{23}$ In other words, there is good reason to think that there was much more Italian landownership than we

\footnotetext{
16 Deniaux I993: 235 suggests that the estates of Atilius (praedia Atiliana) mentioned by Cicero (Att. 5.I.2) were in Bithynia, but on rather uncertain grounds.

17 Bloch [I954]2004: 50-I distinguishes between 'intentional' and 'unintentional' evidence.

18 App., Mith. 47. For other examples see Table I, nos I and 22.

19 cf. Table I, nos 3-5, IO, I4, I 5, I7, 2I.

20 cf. Table I, nos 3, 4, Io, I4, I7 and Table 2, no. 8.

21 cf. Table I, nos 2, 6, 7, 9, II-I3, I6, I 8-20.

22 Lindhagen 2009: I03. On Lindhagen's arguments about Dalmatia as the main production centre for Lamboglia 2 and Dressel 6A see now Panella 20I0: especially 96-7 and Carre et al. 20I4, who quite likely overstate their case when they deny the production of any such amphorae in the eastern Adriatic. Shpuza 20I 6: 234 provides further evidence for the production of Lamboglia 2 amphorae in Illyria.

23 Zoumbaki 20I3: 64. Petropoulos 2009: 49-5I makes an analogous argument concerning a funerary monument in the first century B.C. For Anatolia see Mitchell I993: I43-64.
} 


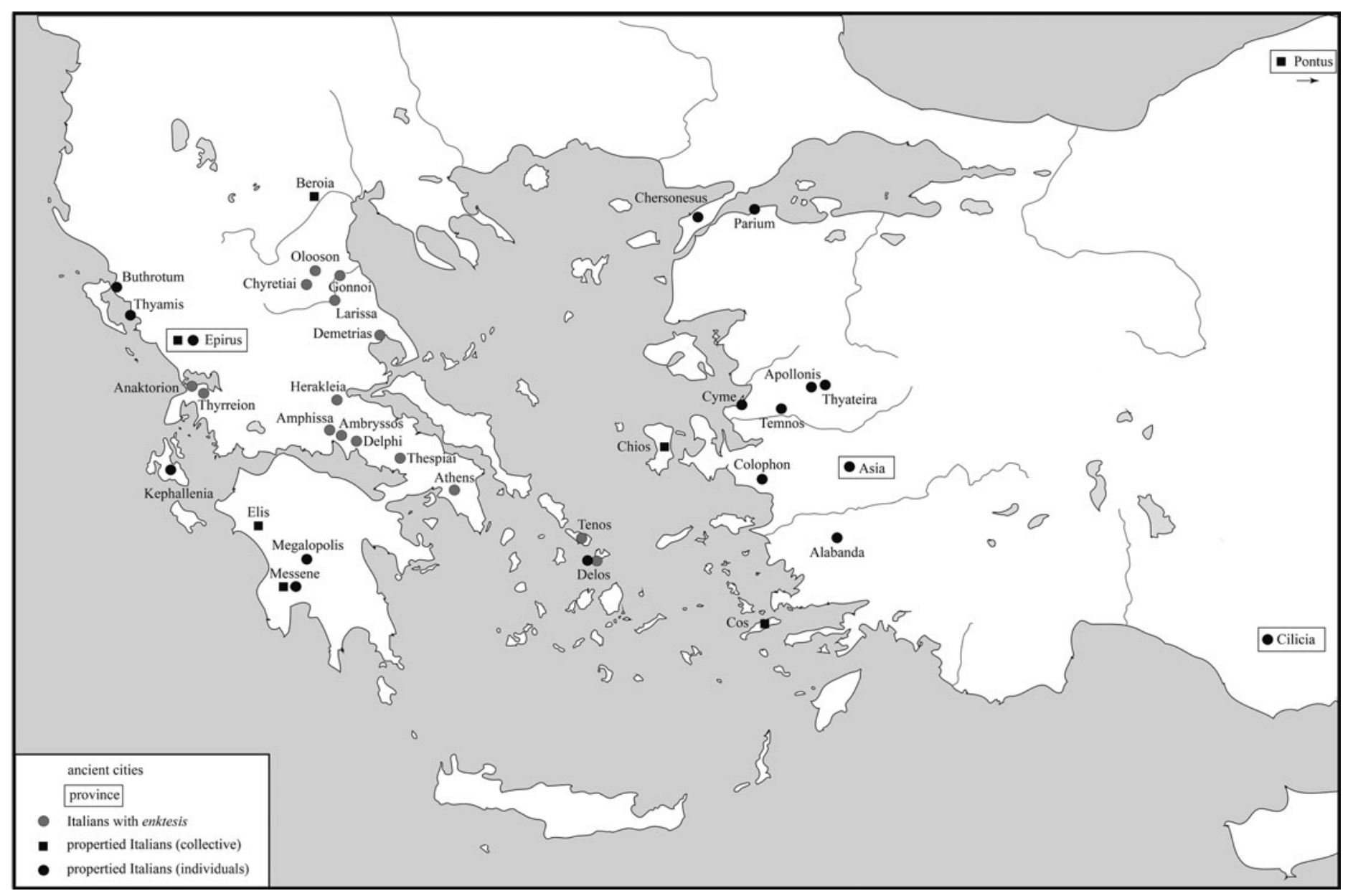

FIG. I. Propertied Italians and grants of enktesis to Italians in the Greek East (third to first centuries B.C.). 
have attested. But even in light of the evidence that we have, the conclusion that Italians owned land just about everywhere - where there was a Roman province, that is seems hard to avoid. What is more, in several places Italians came to own significant parts of various local landscapes.

In the second book of his De Re Rustica, Varro set up his discussion of cattle raising as a dialogue among the Italian 'cattle-breeding athletes of Epirus', as he called them. As a result, the extent of Italian holdings and the considerable number of Italians involved in the agricultural economy on the eastern shore of the Adriatic could never be denied. ${ }^{24}$ The Epirote situation, however, has been treated as an exception, often explained with reference to the mass enslavement of Epirotes after the Roman victory over Perseus. ${ }^{25}$ But there is evidence that suggests similar situations in various other places in the first century B.C. One of them is Messene. For starters, we know the names of five Italian landowners there, as well as the number and the names of their properties. ${ }^{26}$ More importantly, however, a document related to tax-collection names a category of Romans that were evaluated as part of the Messenian territorial tribes, which has been taken as an indication of their landownership there. ${ }^{27}$ The wealth of these Romans, together with that of other foreigners resident in Messene, made up more than a tenth of the total evaluation of the city's population. ${ }^{28}$ It would appear, then, that Italian landownership in the territory of Messene in the first century B.C. was not a rare phenomenon. A Coan inscription by a disparate group of Coans, metics and Romans, who all owned and farmed land in Haleis and Peles, two Coan demes, shows an analogous Italian penetration of the local rural landscape. ${ }^{29}$ In all likelihood Italian possessions on Chios were also quite substantial; Mithridates insisted on receiving tax-revenue from them. ${ }^{30}$ Lastly, there are the inscriptions from Beroia and Elis that identify groups of Italians as

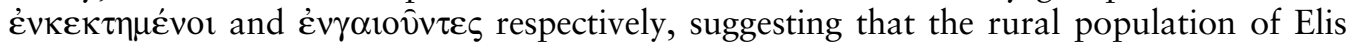
and Beroia might have been penetrated by Italian landowners in precisely the way in which we know it happened in Epirus, Messene, Cos and Chios. ${ }^{31}$ All this evidence combined makes it impossible to continue casting Epirus as an exception, which gives a new dimension to the connection that scholars have made between the enslavement of large parts of the Epirote population and massed Italian landownership in the region. ${ }^{32}$ It serves as an urgent reminder of the massive displacement of previous, local owners that these Italians and their landed estates caused. ${ }^{33}$

Landownership in the diaspora was not the monopoly of any one particular socio-political group. As mentioned above, we find freedmen, equestrians, senators, both exiled and not, and members of the imperial family as landowners. Moreover, many Italian landowners in the Greek East probably did not belong to any of these groups. While we might suspect that at least some of the landowners about whom we have no further information fell into this category, Lucius Genucilius Curvus, whom Cicero introduced to Quintus Minucius Thermus in 5 I/5O B.C., seems a quite certain case;

\footnotetext{
Zoumbaki 2017 .

e.g. Alcock I989: 8; I993: 75 .

cf. Table I, nos 4, 5, I0, I4, I7. Nemerius owns a property called Automeia.

7 cf. Table 2, no. 8 with Zoumbaki I998-99: I I9-20; Grandjean 2003: 254-5; Migeotte 2008: 235-6; Doyen forthcoming.

${ }_{28}$ IG V.I, I433, ll. 8-IO: the total evaluation of property in Messene is I,OI 8 talents; the property of Romans and other foreigners is valued at 129 talents.

29 cf. Table 2, no. 9 and below, Section III.

30 cf. Table 2 , no. 4 .

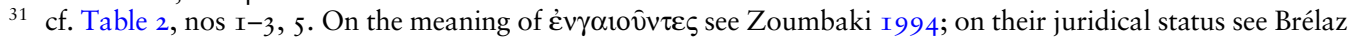
20I6: 8I.

32 See below, Section III.

33 For speculation as to how this displacement could happen - a question that falls beyond the remit of this paper - see Kornemann I900: II96-7; Hatzfeld I9I9: 299-300; Eberle 20 I6.
} 
unlike, for example, Marcus Feridius, whom Caelius introduced to Cicero in the same year, Curvus is not identified as an eques. ${ }^{34}$ The failure to mention his social position within the Roman polity would indeed be a grave mistake by Cicero in a letter designed to impress the urgency of Curvus' business on the governor of the province where his estates were located. It seems likely, then, that among the Italians whose social position we know, our evidence is skewed towards the top, simply because they and their landownership appear much more readily in our sources, especially in ancient historical narratives.

Two more aspects regarding the social composition of Italian landholders deserve highlighting. Based on a passage in Cicero's Verrines Elizabeth Rawson has posited a law that forbade senators from owning land outside of Italy, an argument that Jonathan Prag revived recently by positing a possible context for this law in the late third century B.C. together with the plebiscitum Claudianum. ${ }^{35}$ If Prag is right, the passing of such a law at the time when the earliest provinces were taking shape only helps our case here since the prohibition that it enshrined indirectly reveals that new landholdings were precisely one of the things that senators - and other Romans were hoping for in these new provinces. At the same time, the unapologetic way in which Cicero wrote to his brother about Lucius Flavius' inheritance of an estate in Apollonis in Lydia in 57 B.C. only confirms what Cicero already implied in the Verrines in 70 B.C. - that this law was no longer consistently applied. ${ }^{36}$ The early first century B.c. thus appears a safe terminus ante quem for its desuetude. Lastly, it is worth remembering that in the first century B.C., and possibly already earlier, land located outside of Italy did not count in the census in Rome. ${ }^{37}$ As a result, the Roman socio-political status of Italian landowners in the Greek East cannot serve as an indication of the size of their estates and overall wealth. Atticus' case is illustrative here. His Epirote properties together with his urban properties in Rome made up the main part of his estate. ${ }^{38}$ In other words, possibly half of Atticus' wealth in land did not count for his census valuation in Rome.

Based on the evidence that forms the starting point for this section, Italian landownership in the Greek East would appear to be a predominantly first-century B.C. phenomenon and in most cases would also post-date Mithridates' revolt. As argued above, the dominant position of Cicero's writings as a source casts doubt upon this picture. More importantly, there is evidence that makes Italian landownership in second-century mainland Greece and in pre-Mithridates Asia Minor rather likely. Italians were present in many cities in Asia Minor before 88 в.C.; Mithridates famously had them killed. ${ }^{39}$ They also owned land in at least one of these cities, in Chios. ${ }^{40}$ It seems unlikely that the island was an exception; Mithridates, at least, anticipated taking over all of their possessions. ${ }^{41}$ Also, a dispute between Colophon and its resident Italians in the I IOS B.C. appears to have concerned the landholdings that these men had acquired in the city's territory. ${ }^{42}$ As regards mainland and insular Greece, Italians were present in cities in the third and second centuries B.C., and some of them were granted

\footnotetext{
34 cf. Table I, nos II and I3.

35 Cic., Verr. 2.5.45-6 with Rawson I976: 90-I; I994: 446-7; Prag 2016.

36 Varro, Rust. 2.5.I mentions Quintus Lucienus, a senatorial cattle-breeder in Epirus. For Seneca (Ep. 87.7) it was clear that rich Romans, regardless of their legal status, owned estates all over the empire.

37 Cic., Flac. 80 with Bleicken I974: 374.

38 Nep., Att. I4.3.

39 See Cic., Flac. 60 and App., Mith. 2I with Kirbihler 2007a: 22-3 for the possibility that a lot of the inscriptional evidence for these men and women was destroyed as part of Mithridates' revolt. Kirbihler 2007a: 32 also provides a map of all the places where collectivities of Italians in Asia Minor are attested before 9I B.C.

On the 'Asian Vespers' see App., Mith. 22-3, 28; Val. Max. 9.2-3; Plut., Sull. 24.4.

40 App., Mith. 47.

41 App., Mith. 22.

42 SEG 39, I 244, col. I, ll. 23-7 with Ferrary I99I: 566; contra Fournier 2010: 426-7.
} 


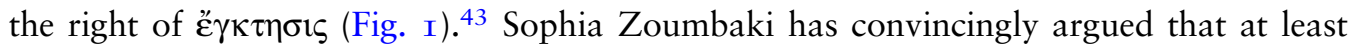
three awards of enktesis to Italians in central Greece - by the Acharnanian League, Amphissa and Delphi - were not simply part of a standard set of honours that foreigners could receive in these polities; instead, they are exceptional enough in their context or formulation to suggest that the awardees were actively interested in this particular right and in making use of it. ${ }^{44}$ The late second-century B.C. Latin funerary inscription for a liberta from Lake Trichonion should also be added here, in addition to the four Italians who rented properties on Mykonos and Rheneia in the I 5 Os B.C. In this context it is also worth mentioning Pandusinus' involvement in the agricultural economy in Thisbe in I 70 B.C., which most likely accompanied Roman military campaigns in the region. ${ }^{45}$ However, it remains hard to say anything more specific than that we need to look to the late third and second century B.C. - to the period that saw increasing Roman military and administrative involvement in the region - for the beginnings of Italian landownership in the Greek East.

While Italian landownership increased over time, it was also disrupted, intensified and manipulated in the context of the 'big events' of the period. As cities in Asia Minor joined Mithridates' cause, they expropriated the landholdings of the Italian populations living in their midst. After Mithridates' defeat Italians returned. The Chians, for example, made sure to get the Senate's guarantee for the conditions under which Italians were to live in Chios henceforth. ${ }^{46}$ The Sullan settlement also meant a windfall of land for Italian creditors, as cash-strapped cities offered them their public property, including land, as collateral, and more generally, we should imagine that after Mithridates' defeat barely any city dared resist the requests and desires of the diaspora. ${ }^{47}$ Later in the first century B.C. Pharnaces' invasion of Pontus and Bithynia caused a similar dynamic concerning Italian landownership in these parts of the empire. ${ }^{48}$ However, the colonial foundations of Caesar and Augustus in the second half of the first century spelt the most fundamental and lasting alterations in the existing patterns of Italian landownership in the Greek East. ${ }^{49}$ Pompey had already settled some of his veterans in Bithynia, Cilicia, Crete and Macedon, but the settlements of Caesar and Augustus were on an unprecedented scale. ${ }^{50}$ These two men increased the number of Italian landowners in the provinces, but their foundations also threatened many existing ones. Atticus' frantic correspondence with Cicero about Caesar's testament, Mark Antony's execution thereof, and the plan to place a colony at Buthrotum, where Atticus' own estates were located, provides a good illustration of the disruption in the patterns of Italian landownership in the Greek East that these colonies could mean. ${ }^{51}$

The Caesarian and Augustan colonies have rarely been treated in connection with the Italian diaspora, let alone with the diaspora's landholdings, a scholarly division that we have followed as well in this section so far. ${ }^{52}$ The overwhelming geographical extent of

43 Hatzfeld I9I9: I-5 I remains foundational. For regional summaries see Helly I983: 358; Bouchon 2007: 2689 (Thessaly); Follet 2002 (Athens); Müller 2002: 90-2 (Boiotia); Zoumbaki I998-99; 20 I 2: 78-80; 20I4a: 327; 20I7 (Phocis, Locris, Peloponnese, Cyclades and Adriatic coast); Rizakis 2002: I I 2-20 (Macedon). Zoumbaki 20I3: 55-62 provides an exhaustive list of the Italians that were granted the right of है $\gamma \kappa \tau \eta \sigma t \varsigma$ in the region.

44 IG IX.I, 5I3; SEG 52, 543; Syll. ${ }^{3} 585$ with Zoumbaki 20I3: 57-9.

45 IG VII, 2225, 1l. 53-4 with Müller 2002: 92, who makes a case for his involvement in both production and distribution.

46 RDGE 70, ll. I7-I8 with Marshall I969.

47 App., Mith. 63 with Broughton I938: 517-18.

48 cf. Table 2 , no. 7 .

49 For these foundations see the lists and maps at MacMullen 2000: 8-9.

50 Caes., B.Civ. 3.4; Dio Cass. 36.50.3.

51 cf. Table I, no. I9. Deniaux I987: 250-3 provides an account of the negotiations. For Atticus' prominence in the newly founded colony see Sestieri I943: 63, n. 6 .

52 Purcell 2005: 96-7 is a clear exception. 
Italian landownership as well as the density of the Italian penetration of several rural landscapes of the Greek East that we have uncovered in this section makes this relationship an interesting research problem. Again, Adam Lindhagen's research on Narona, in particular on the amphora production on Vis, a small island off the Croatian coast where the city was located, provides some intriguing insights. In the late first century B.C. Narona became a colony. While this refoundation of the town did not interrupt the amphora production in Vis, it did change the names of the people whose stamps could be found on the vessels: members of senatorial families seemingly took over the organization of the production from freedmen and other Italian families. ${ }^{53}$ In other words, as the socio-political profile of the community changed, its economic mainstay, the production and export of wine, did not. Strabo also tells us that the Roman colonists at Patras made sure to own the rights to fish a lake near Aitolian Calydon that was renowned for its oysters, which were also consumed in Rome. ${ }^{54}$ In so doing, these colonists followed precisely the same economic strategies that many Italian landowners in the Greek East had done before them. This, at least, is what the following three case studies suggest.

III THE EXPLOITATION OF ITALIAN ESTATES IN THE GREEK EAST: THREE CASE STUDIES

In this section we present three case studies that examine the exploitation of Italian estates in Epirus, Cos and Chios, and Melos, respectively. We chose these regions with a view to examining Italian behaviour in different ecological contexts and in relation to different types of resources and products. This variation helps us to discern a pattern and strengthens our argument that such a pattern existed. At the same time, the radically different types of evidence that form the basis for each study bring to the fore more clearly aspects of the exploitation of Italian estates of which other case studies might only reveal glimpses. As such, the different cases also build on each other argumentatively. Overall, each case study constitutes a chapter in the history and geography of the region in question, an examination of how the Italians shaped the environment that they encountered and what this meant for local social, political and economic life. Put in the language of the Corrupting Sea, each case study explores how these regions became 'the outposts of the demographic and economic dynamics of a wider world'. ${ }^{55}$ In our case this world and its demographic and economic dynamics were those that Roman imperialism created.

\section{Epirus}

As Nikola Čašule has argued, the Adriatic was an interconnected entity. The networks that shaped these connections - networks that the Romans most likely joined when they founded colonies on Italy's Adriatic coast in the third century B.c. - were constantly bringing Italians to Illyrian and Epirote cities on the other side of the sea. These were the men whose alleged mistreatment in the third and second centuries B.c. repeatedly involved Rome in military conflicts with the dynasts that ruled over the eastern shores of the Adriatic. ${ }^{56}$ As a result, Samnite and Messapian names at third-century B.C. Dyrrachium should not come as a surprise, and neither should the funerary inscription

53 Lindhagen 20I3: 243, 245. On datable Adriatic amphorae in Rome see now D'Alessandro and Sebastiani $20 \mathrm{I} 2$.

54 Strabo I0.2.2 I with Rizakis I996: 274-87 and Zoumbaki 20I 2: 87. See Strabo 8.6.23 with Wallace-Hadrill 2008: 395 on Roman colonists at Corinth who dug up old graves in pursuit of grave-goods, bronzes and terracottas, which they sold in Rome as necrocorinthia.

55 Horden and Purcell 2000: 76.

56 Bertrand and Botte 20I2; Cašule 20I2; Shpuza 2016: 225-7; Zoumbaki 2017. 


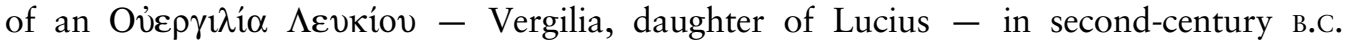

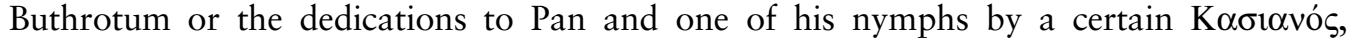
probably a Greek transcription of the Latin name Cassianus. ${ }^{57}$ Just like the Italians that manumitted their slaves under the auspices of Asclepius in second-century Buthrotum, Vergilia and Cassianus participated in local social and commemorative practices that were common in the city. ${ }^{58}$ Beginning in the second half of the second century B.C., however, archaeology hints at the possibility of a very different type of Italian presence in the Epirote landscape.

In recent years archaeologists working on the Thesprotia survey in the Kokytos valley to the north-east of the Ambracian gulf have discovered a villa complex on one of the spurs of the Paramythia mountain range that border the valley to the west. ${ }^{59}$ Located at Agios Donatos, this complex covers an area of about 90 by $40 \mathrm{~m}$ and stretches over three terraces. On the site the excavators found a tile with a Latin stamp - COS - and one of the rooms had well-preserved wall-paintings in the Second Pompeian style. Most importantly, however, the earliest phase of the complex, which coins and pottery date to the second century B.C., was already built in opus incertum. This site now constitutes the earliest known villa complex in Epirus, and the evidence found there is among the best that archaeology can provide for identifying an Italian owner. ${ }^{60}$ This owner must have had a very different relationship to local economic, social and political life from that of the Italians attested in the epigraphic material from Buthrotum. Among other things, his diet demonstrably differed from that of many members of the local population: animal bone assemblages from the site contain the bones of wild animals such as deer, luxury food items that other contemporary bone assemblages from the region lacked. ${ }^{61}$ Most tellingly though, the entire villa complex was built on the site of a Hellenistic fortress. For now it remains impossible to know the relationship between Aemilius Paulus' slave-hunting campaigns in I67 B.C., the destruction of the Hellenistic fortress, and the Italian man who acquired the estates that we should assume accompanied the villa complex. Crucially though, the sequence of buildings at Agios Donatos illustrates that the Italians who began acquiring land in Epirus in the second century B.C. did not simply move into empty lots in the landscape that the slave-hunting of Aemilius left; their presence also altered social, economic and political life in the region. ${ }^{62}$

Italian landownership in Epirus in the first century B.c. has never been in doubt. In the second half of that century Varro could make Italian landowners in Epirus five of the six interlocutors in the second book of his De Re Rustica: T. Pomponius Atticus, L. Cossinius, Qu. Lucienus, Murrius and Vaccius. ${ }^{63}$ And these were clearly not imaginary characters. Atticus was of course Cicero's friend, and L. Cossinius probably was the man of the same name who appeared in their correspondence. ${ }^{64}$ According to members of the Thesprotia survey, the COS on the tile they found abbreviated his name, making him the owner of the villa complex at Agios Donatos. ${ }^{65}$ Atticus, we know, purchased his estate in Epirus, his emptio Epirotica, in 69 or 68 B.c., and he had a domus in Buthrotum and properties along the Kalamas river further south. ${ }^{66}$ The villa complex at

57 Čašule 20I 2: 223-4 (Dyrrachium); I.Bouthrotos I 82-3 and I97.

58 I.Bouthrotos 2I, ll. 9 and II; 22, ll. I3-I 4; 29, 1. 49; 37, 1. 3.

59 Forsén and Reynolds 20II; Forsén 20II: 17-22.

60 On Roman villae in Epirus see Bowden 2003: 60-7; Bowden and Përzhita 2004: 424, n. 34; Bowden 2009: I7I, all dated to the first century A.D. Bowden and Përzhita 2004: 4I9 mention a possible late Republican phase for the complex at Diaporit near Butrint and Shpuza 2016: II9-23 for villae in Illyria and Chaonia.

61 Niskanen 2009; Forsén 20II: 2 I.

62 Shpuza 2016: I22-3 discusses villae in northern Epirus that are reworkings of defensive buildings.

63 Varro, Rust. 2.I.2, 2.2.I.

64 Cic., Att. I.I9.I I, I.20.6 and 2.I.I.

65 Forsén 20II: I8.

66 Cic., Att. I.5.7, 2.6.2, 4.8.I; Cic., Leg. 2.3.7. Two of Atticus' freedmen were buried at Buthrotum: 
Agios Donatos, which is $18 \mathrm{~km}$ from the sea, now conclusively shows that the Italian presence in Epirus was not limited to the coastal plains. One of Cicero's letters of recommendation to L. Culleolus, governor of Macedon, further confirms this picture: he asked Culleolus to concern himself with the dispute that a certain L. Lucceius had with the town of Byllis, located on a hill overlooking the Aous river as it entered the coastal plain around Apollonia. ${ }^{67}$ The town was the centre of the koinon of the Bylliones, which controlled large upland territories in southern Illyria. ${ }^{68}$ While we do not know whether the dispute involved land, Italian interest in land that lay not only beyond coastal, but also beyond river plains seems highly likely in light of the type of agriculture in which Italians in Epirus were notoriously involved: transhumant pastoralism. 69

Already in the Classical and Hellenistic periods Epirus and its hills were famous for pasture land and the cattle raised there. Pindar knew the Epirote mountains as 'pasture loved by cows' and Aristotle attributed the Panhellenic fame of Epirote cattle, which was due to their extraordinary size and the large amount of milk that they gave, to the fact that the region had an appropriate grazing ground for every season. ${ }^{70}$ The fact that up until the early nineteenth century the coastal plains in Epirus, in particular around the mouths of rivers, were substantially smaller than today will have made the highlands all the more important in the economy of the region. ${ }^{71}$ No archaeological evidence exists that would allow us to quantify the rôle of pastoralism in the Epirote economy, but anecdotes about the Epirote kings speak to its importance. Pyrrhus and his family, Aristotle and Pliny tell us, took pride in having their own flocks of cows and sheep to whose well-being they tended and whose extraordinary qualities - qualities that they in fact bred for - might also have been meant to reflect back onto the king and his family. ${ }^{72}$ In this titbit of royal ideology the king and his family emerge as the most successful pastoralists in Epirus - a reflection of the specific economy of the region in which these Hellenistic kings originated. Thus when Italians in Epirus became involved in cattle raising, they tapped into the distinct ecological potential of the region. The second book of Varro's De Re Rustica, in which Italian landowners in Epirus expound upon the principles of cattle raising, provides a good indicator for how these men might have approached their holdings. Two separate but related aspects deserve highlighting: the interest of Varro's characters in the entire production process, including the buying and selling of the animals, and the importance of the animals' quality, which pervades the entire book.

Varro's characters did not let out their estates to tenants but retained control of the exploitation of their agricultural resources through the unfree labour of a magister pecoris and other herders under his command. ${ }^{73}$ This exploitation also involved selling the cattle. The advice of Varro's characters for how to deal with each type of cattle always included the legal formula according to which it should be sold. ${ }^{74}$ What is more, where and why their animals were sold was a source of pride for these men. One of

I.Bouthrotos 200 and 20I. For Varro, Rust. 2.2.2 and the possibility of Italian holdings at Epirote Pergamon and Maledos compare Ennius' Annales (io, 1. 342, ed. Skutsch).

67 Cic., Fam. I3.42 with Diaz Fernandez 201 I on Culleolus.

68 On the extent of Byllis and the koinon of the Bylliones see Ceka I987: especially I42.

69 Varro, Rust. 2.5.I I. Whether this interest in upland pastures took the form of ownership or grazing rights epinomia - remains unknown. For instances of Italians acquiring epinomia see SEG 52, 543 (Amphissa) and IG V.2, 456 (Megalopolis).

${ }_{70}$ Pind., Nem. 4.83; Arist., Hist. An. 3.2 I. Cabanes I976: 490-2 and Chandezon 2003: 102-5, 400-1 8 discuss pastoralism in Hellenistic Epirus.

71 Besonen et al. 2003; Jing and Rap 2003; Tartaron 2004.

72 Arist., Hist. An. 3.21, 7.8; Plin., HN 8.176 with Levêque I957: 227.

73 Varro, Rust. 2.I.24 and 2.I0.4-5.

74 Varro, Rust. 2.2.5-6 (sheep), 2.3.5 (goats), 2.4.5 (pigs), 2.5.I I (cows), and 2.7.6 (donkeys). 
them bragged that he had sold some of his asses in Arcadia, a place that was renowned for its mules. ${ }^{75}$ More generally, Varro probably chose the Italians in Epirus - the 'cattle-breeding athletes of Epirus' as he calls them - as the characters in his book on pastoralism because of their animals' renown. Together these interests and attitudes point to a highly commercialized form of pastoralism focused on high-end animals.

And indeed, different animals from Epirus were luxury goods in the late Republic, albeit on different levels. Most prominent are Epirote horses, which Romans in the late Republic and early Principate liked to use for racing. ${ }^{76}$ Just like asses, they could fetch high prices and most likely were the object of focused breeding efforts. ${ }^{77}$ Much more affordable a cheaper luxury, one might say - were Epirote cows, known for their size, which according to Varro were used in just about any context in Italy except for sacrifice. ${ }^{78}$ This widespread use and consumption of Epirote animals in Italy should be taken seriously. In the case of Epirote racehorses, for example, it seems possible that Italians in Epirus bred their horses purposefully with consumers in Rome and Italy in mind, among whom horse racing was becoming extremely popular. ${ }^{79}$ As regards cattle, one might wonder whether the Italians involved in cattle raising in Epirus reorganized the existing networks for ferrying these animals across the Adriatic to Italy. ${ }^{80}$ Overall, animals from Epirus appear to have fed directly into the consumer revolution that was taking place in Italy in the second and first centuries B.C. ${ }^{81}$

The extent to which the agricultural strategies of Italian landowners in Epirus differed from those of their Epirote counterparts remains impossible to know but in the second and first centuries B.C. the Epirote socio-economic landscape underwent significant changes that might have been the result of the Italian involvement there. While at least two enclosures that were used as part of transhumant regimes in northern Epirus show continued use across Hellenistic and Roman times, settlement patterns within the region do not reveal such continuity. ${ }^{82}$ Instead, over the course of the first century B.C. settlements located in the uplands regions were increasingly abandoned. ${ }^{83}$ Many factors can explain this combination of change and continuity, but the dynamics of transhumant pastoralism suggest a very specific one. As has been shown in the case of the pastoral regime in Thessaly and between the Zagros mountains and the Mesopotamian floodplains, people involved in transhumant pastoralism can be based in the mountains or in the plains. ${ }^{84}$ In other words, herds might migrate from their base in low-lying valleys into summer pastures in the mountains or the other way around. Changes in the balance between these two regimes were highly contested, and in the Mesopotamian context at least were also often brought about through military conflict. Heracleides Lembos, writing in the second century B.C., preserves a glimpse of such upland pastoralists in Epirus. ${ }^{85}$ The abandonment of upland sites in Epirus thus very likely reflects a change in the fraught balance between highlands and lowlands, with pastoralists based on the coastal plains extending their grazing rights at the expense of

\footnotetext{
75 Varro, Rust. 2.I.I4 and 2.6.I. For other men in the world that Varro is describing who took pride in the quality of their cattle see Varro, Rust. 2.pref.6 and 2.I.2.

76 Virg., G. I.56-9; Stat., Achil. I.420.

77 Varro, Rust. 2.I.4 and 2.8.3; Plin., HN 8.45 (asses); Varro, Rust. 2.7.I 5 with Étienne 2005: 244, n. Io (horses).

78 Varro, Rust. 2.5.IO.

79 On the breeding of cattle and sheep in ancient Italy see MacKinnon 2004 and 20I 5: 252-73.

80 On the ferrying of animals on the ancient Mediterranean see Chandezon 2003: 28 5-8 and Strabo 4.6.2; 6.2.7.

81 Wallace-Hadrill 2008: 3 I 5-440 discusses the archaeologically traceable aspects of these changes.

82 Shpuza 20II: 6I4-I 5 discusses two such enclosures at Ripësi and Paleomanastri respectively.

83 Shpuza 20II: 6I0; 2016: I30.

84 Reinders and Prummel I998; Greco 2003.

85 FHG II, 219, 33 with Cabanes I976: 49I on the location of the territory of the Athames whose way of life Herakleides described.
} 
those based in the mountains. The chronological correlation of this change with Italian landowners in Epirus and the heavily commercial type of pastoralism they practised is tempting and raises the distinct possibility that the Italians played a part in displacing the people in these highland settlements. ${ }^{86}$

In sum, starting in the second century B.C. Italians were involved in the agricultural economy of Epirus, acquiring large estates and showing a distinct interest in the pastoralist potential of the area. They were particularly keen on high-quality animals, on their breeding and subsequent marketing, to Italy in particular. As such, their agricultural strategies were highly commercial in nature and most likely had deep-running consequences for the forms of social organization prevalent in the region. But Epirus, one might argue, was exceptional - not only because of Aemilius Paulus' slave-hunting campaigns, but also due to its various connections with the Italian peninsula that long predated Rome's rise to prominence. In the next case study we focus on the islands of Cos and Chios, and the mainland opposite them to argue that what for Italians in Epirus was cattle, for those in the western Aegean was wine. Empire, it would appear, brought certain parts of the world closer together.

\section{Cos, Chios and Beyond}

By the first century B.c. Italians owned land in both Chios and Cos. As regards Chios, Appian tells us that the city and Mithridates came into conflict in the aftermath of the murder and exile of the Italians on the island because the citizens of Chios cultivated the properties of the Italians who had left, but refused to pay taxes on these properties to Mithridates. ${ }^{87}$ This episode not only testifies to the existence of Italian landholding on the island before 88 в.c., but Mithridates' eagerness to collect taxes on these landholdings also suggests that the revenue he derived from them was substantial, which could be taken as an indication of their extent. A few years after Mithridates' defeat Italians appear to have been back on Chios in sufficient numbers to prompt the definition of their legal position in a senatus consultum in 80 B.C. ${ }^{88}$ These Italians also left their footprint in the island's epigraphic material from the first century B.C. ${ }^{89}$ On Cos, the first attestation for landownership stems from the Augustan period when a group of people calling themselves 'those residing in the deme of the Halentians and those having the right to own land and those farming in the demes of Haleis and Peles, of the citizens, the Romans, and the metics' honour a public physician. ${ }^{90}$ While this is the first attestation for Italians' involvement in agricultural production on Cos, they were clearly already present before that date. ${ }^{91}$ Stamps on Coan and Chian amphorae make it likely that at least some of them were interested in the viticultural fame and potential of these islands.

It has been known for a long time that Coan amphora handles, easily recognizable by their double-barrelled handles, also bore Latin stamps. ${ }^{92}$ Susan Sherwin-White first

\footnotetext{
${ }^{86}$ For another possible local impact of the Italians - their rôle in shifting Epirote preferences from collective to individual ownership of slaves - see Bowden 2009: I68-9.

87 App., Mith. 47.

88 RDGE 70, ll. II-I7. Marshall I 969 argues that the dispute leading to this senatus consultum was about land.

89 e.g. McCabe I986: nos I 5 (= IGRR IV I703) and I9I (honorific decree and dedication for Lucius Nassius), and no. 29 (fragmentary list of magistrates, containing a Lucius Fabrinius and a Decimus). Intriguing, but not clearly datable, is also McCabe I986: no. 5 I I (somebody apparently practising Latin repeatedly wrote 'Cassius'). 90 cf. Table 2 , no. 9.

91 e.g. IG XII.4.2, 505 (Aulus Ofellius honours Asclepius with a dedication, first century в.C.); IG XII.4.2, 5 I 3 (a certain Cluvius, identifying himself as Minervalis, honours Minerva in Latin, first century B.C.); and IG XII.4.2, I026 (cives Romani qui Coi negotiantur honour the island for its attachment to Julius Caesar, 48-44 B.C.). See also Bosnakis 2008: nos I4, 6I, I23 for examples of Roman praenomina and gentilicia on second- and first-century B.C. tombstones on Cos.

92 Sherwin-White I978: 252 , n. I 84 .
} 
mentioned this intriguing fact in print and attributed her information to the late Virginia Grace, who had spent her entire life working on these stamps without ever publishing the long-awaited corpus. Our argument here relies for the most part on the stamps we were able to consult in Grace's personal papers that are currently housed in the archives of the American School for Classical Studies in Athens. We begin by outlining our findings there. In 1958 Grace compiled a list of names written in Greek on Coan amphora handles, which she sent to Peter Fraser for the Lexicon of Greek Personal Names. In 1984 she drew up an additional list to be added to the previous one. These two lists contain five Italian names written in Greek. ${ }^{93}$ More significantly, Grace also worked up a card catalogue for the names found on Coan amphorae, often also including a picture of the stamp itself and annotations about where she found and saw them. The catalogue again only concerns the names written in Greek, but at the back of it, behind the cards with stamps that she had not read or identified yet, are stored six index cards and many more photos of Coan amphora handles bearing stamps of Latin names. ${ }^{94}$ They make up a total of twenty-eight distinct handles showing the stamps of twenty-one distinct individuals. ${ }^{95}$ As indicated by the annotations on the back of the pictures, twenty-one of the twenty-eight handles come from the Benaki Collection in Alexandria, which Grace helped sort and catalogue in $1955 .{ }^{96}$ Another two she saw in Athens, and three more in Antioch, Cos, and in the collections of the British Museum respectively. The origin or location of the remaining two is unknown. This relatively small number of stamps says nothing about the volume of production in which these Italians were involved since Coan amphorae appear to have been stamped very rarely. ${ }^{97}$ By contrast, the names of the individuals on these stamps reveal a lot about the place and organization of land in the economy of Italians in the diaspora.

Both common interpretations of stamps on Italian amphorae and recent models proposed for Greek amphorae suggest that the men whose names these stamps record were involved in agricultural production on the island. ${ }^{98}$ Most likely they had these amphorae produced for the storage and transport of the wine from their estates. Based on this assumption, it seems worth noting that at least four of the individuals named on Coan handles - Publius Arpinius, Postumius Curtius, Lucius Eumachius and Publius Sulla - have also been recorded on Italian amphorae. ${ }^{99}$ Intriguingly Murrius, the character in Varro's dialogue discussing asses and horses, states that he came from

\footnotetext{
93 American School of Classical Studies at Athens, Archives, Virginia R. Grace Papers, Drawer I4, File 625. The

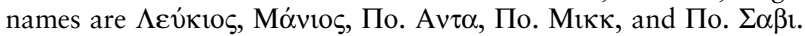

94 American School of Classical Studies at Athens, Archives, Virginia R. Grace Papers, Kartoules, 'Koan'.

95 Six of these stamps were not legible to the authors, but were clearly distinct from each other. Another five were legible, but no individual names could be read. The ten remaining stamps name a Cario and a Cerdo; an Albius, an Antonius and an Ovinius; and Publius Arpinius, Postumius Curtius, Lucius Eumachius, Gaius Livius and Publius Sulla.

96 Grace I966: 286.

97 Empereur I982 and Finkielsztejn 2004: I 54 arrive at estimates of between I and IO per cent.

98 On Italian amphorae see Tchernia I986: I I9; Zaccaria I989: 473-4; Manacorda and Panella I993: 57. On Greek ones see now Lawall 2005: 194-6, contra Garlan 1993, who presents the classic case that stamps on Greek amphorae were about civic certification. See also Finkielsztejn 2006: I34 on the stamp of Vedius Pollio on Chian amphorae, where he simply calls him a 'grand propriétaire' on Chios without much explanation.

99 For Publius Arpinius on Italian amphorae see Garozzo I999: no. 55; Desy 1989: no. I094. For Postumius Curtius see Callender I965: no. I37I; Tchernia I986: II7, n. 234; CIL X 8051, 26. For Lucius Eumachius see Tchernia I986: I5I; Freed and Moore I996: 21-2. For Publius Sulla see Manacorda I989: 45I. Some of these Italian amphorae were of the Dressel 2-4 type - a type modelled on Coan amphorae - which raises the possibility that some of the handles, whether on the Coan side or on the Italian side, were wrongly identified. As for the Italian side, it is worth pointing out the presence of Dressel I and Brindisi amphorae among the Italian vessels bearing stamps that are also found on Coan amphorae. As for the Coan side, we are bound to trust Grace, and based on the details concerning the Benaki Collection, we have good evidence to do so. Grace clearly saw that this collection contained stamps on Italian vessels (Grace I966: 286), including the stamps of Lucius Arpinius, which Benaki identified as coming from Brindisi and Italian Dressel 2-4 amphorae (Benoit
} 
Reate, the best region for these animals in Italy. ${ }^{100}$ One might wonder whether he had also already bred animals there. At least some of the Italians in the diaspora, then, extended the type of agriculture they practised in Italy to the provinces.

Furthermore, some Italians were demonstrably involved in viticultural production in more than one city. Postumus Curtius, whose name can be found on Coan amphorae handles, provides a good example. Probably he became Rabirius Postumus by adoption, Cicero's client 'cuius res in pluribus provinciis versata est'. ${ }^{101}$ His freedman Gaius Curtius Mithres had a house in Ephesus while also being involved in a dispute over land in Colophon. At the same time, he was also honoured by the city of Naxos, yet another place famous for its wine. ${ }^{102}$ Curtius Mithres, then, was a man with properties in different cities and we might wonder whether he also looked after the interests of his patron there. Notably, both Varro and Cicero repeatedly see Atticus and the other Italians on the eastern coast of the Adriatic as being simply in Epirus rather than in distinct cities there. ${ }^{103}$ They most likely saw an analogous region in Western Asia Minor, in which Italians were involved in agricultural production across civic boundaries, exploiting, just as in Epirus, a particular ecological potential of this part of the world: viticulture. ${ }^{104}$

Vedius Pollio, probably the most well-known member of the Italian diaspora, illustrates both these aspects very well: he most likely owned properties in both Chios and Cos - his name, at least, can be found on both Coan and Chian amphorae - and his father, Horace tells us, worked I,, 00 ingera of Falernian land. ${ }^{105}$ While Pollio's rise to political prominence under Augustus might have been exceptional - he acted as a representative of the first emperor in Asia - his economic strategies in the provinces, though in part certainly located at the very high end of the luxuries available from there, would thus appear to have been less so. ${ }^{106}$ As a result, one might speculate that his fiscal privileges recorded in the Lex Portorii Asiae, while probably being a result of his political position, also reveal economic behaviour that was representative of his fellow viticulturalists in Western Asia Minor. ${ }^{107}$ From this document it would appear that Pollio enjoyed a complete tax immunity on exports from and imports to the province of Asia, a situation that was slightly modified in I7 B.C., when only shipments of his that did not exceed the value of 10,000 denarii were to enjoy such immunity. ${ }^{108}$ In order for this limit to be a meaningful restriction on Vedius Pollio's privileges, he must also have been involved in transporting goods on a large scale, possibly including the products of his own estates. ${ }^{109}$ So what in the case of the Italians raising cattle in Epirus we could already see glimpses of, also seems probable in the case of Vedius Pollio and his fellow

I956: 26). In other words, the stamp of Publius Arpinius in this collection, as well as those of Publius Sulla and Postumus Curtius, will not have been classified as Coan without good reason.

100 Varro, Rust. 2.6.I.

101 The quote is from Cic., Rab. post.4. On the identification and its history see Manacorda I989: 45I.

102 Cic., Fam. I3.69; BE I970, 438 with Zoumbaki 2014a: 328.

103 e.g. Varro, Rust. 2.pr.6, 2.I.2, 2.2.I, 2.5.I; Cic., Att. I.5.7, 2.I 5.2, 5.7.I.

104 Strabo I4.I.I 5, I4.2.19.

105 Freed and Moore I996: 22 (Coan); Finkielsztejn 2006: I25-8 (Chian); Hor., Epod. 4.I3 with Kirbihler 2007b. On Pollio more generally see Syme I96I; Kirbihler 20I6: especially 256-64, 384-6; Kirbihler 20 I 7.

106 On the reputation of Chian wine see Plaut., Poen. 699; Strabo I4.I.I 5; Plin., HN I4.73; Ath. I.32e-f. For it being mentioned in one breath with Falernian wine see Hor., Sat. I.I0.24; Tib. 2.1.27-8.

107 Kirbihler 2007b: 269-70 suggests that Pollio's father had interests in the province of Cilicia.

108 SEG 58, III 5, $\mathbb{S} 4$, 11. 96-8 with Cottier et al. 2008: 62-3, I42, 218, 242. This law also holds that items carried 'for private use' were tax-exempt, restricting these exemptions over time (11. 58, 62, 8I-7). Plin., HN I 4.96 reports that L. Lucullus brought back 35,000 litres of Greek wine from his command in Asia and distributed it among the people. One might wonder whether such shipments counted as 'private use' and were thus tax-free.

109 For comparison, Varro, Rust. 3.2-I I discusses an estate of Marcus Seius, which yields 50,000 denarii per year. Based on the association of Pollio's amphorae with places used by Herodes, Finkielsztejn 2006: I35-8 speculates that he delivered some of his wine to that king, who, just as himself, was a friend of Augustus. 
landholders on Cos and Chios; they not only owned agricultural resources in the provinces, but were also involved in moving and commercializing their products.

The onomastic material from Coan stamps also reveals aspects of the social composition of the Italians involved in the production of wine on the island. With Publius Sulla, whose stamp also shows a caduceus and who was possibly the nephew of Lucius Cornelius Sulla, they included at least one member of a senatorial family, who himself was at some point a member of that body. ${ }^{110}$ Analogously to Atticus in Epirus, we also find at least two equites: Rabirius Postumus and Vedius Pollio. ${ }^{111}$ Plotius Tucca, whose stamp was recently identified on a Coan amphora at Carthage and who most likely is the man known as the executor of Virgil's literary estate, should probably also be counted among them. ${ }^{112}$ Coan stamps also reveal members of different Italian gentes: the Albii and the Antonii. Based on the information provided on the stamps, it is impossible to identify these men any further, but they left their mark on the social make-up on the island of Cos; men and women carrying these names can be found in the epigraphic material on Cos from the first century A.D. ${ }^{113}$ It is impossible to say whether these were their freedmen or direct descendants, but we should allow for the possibility that at least some of the Italians involved in viticultural production on the island also settled there. ${ }^{114}$

While the trade in Coan wine has been chronically under-estimated, recent research locates Coan amphorae on sites all over the Mediterranean and the Black Sea, including Italy. ${ }^{115}$ At second-century B.C. sites in the Levant such as Marissa, Coan amphorae are second in quantity only to those of Rhodes and far ahead of amphorae from other Greek cities. ${ }^{116}$ A preliminary and certainly still insecure estimation of volume development on sites in the Levant, Cyprus and Egypt has revealed a sharp increase starting $c$. I 50 B.C. ${ }^{117}$ By the late second century B.C. slaves working in vineyards and the production and sale of particular wines on Cos were regular and reliable tax bases. ${ }^{118}$ Thus when Italians arrived on Cos, the population of the island was already heavily involved in the production and export of wine on a large scale. As the findspots of the Coan handles bearing Latin names show, the wine that these Italians produced was distributed along the same routes as other Coan amphorae in the eastern

110 For the assumption that the Publius Sulla found on Italian amphorae is the nephew of the dictator see Manacorda I989: 45I. Marek 2006: 288-90 counts at least five possible men called Publius Sulla in the first century B.C., all of them with senatorial careers.

111 For Rabirius Postumus as eques see Nicolet 1966: 307, I000-2. For Vedii on Cos see Kirbihler 2007b: 265 n. $2 \mathrm{I}$.

112 Freed and Moore I996: 22.

113 Publius Albius Niger (IG XII.4.2 473, 1l. 7-8); Marcus Antonius Quinctus, son of Marcus (IG XII.4.I, 365 , 11. I 3 I-5); Lucius Antonius, son of Lucius (IG XII.4.I, 365, 1l. I 5I-3); Lucius Antonius Bassus, son of Lucius (IG XII.4.I, 365, ll. I6I-3); Marcus Antonius Quinctus, son of Marcus, the younger (IG XII.4.I, 365, 11. I86-8); Marcus Antonius Capito, son of Marcus (IG XII.4.2, 474, ll. I4-I 5). The absence of any Greek names among these men, who, with the exception of the last one, were all priests of Apollo at Halasarna in the second half of the first century A.D., makes it unlikely that they obtained their citizenship through Mark Antony. For Antonii on Delos see Müller and Hasenohr 2002: I87, 222. For Plotii on first-century A.D. Cos, see Quintus Plotius Rufus, son of Quintus, and Quintus Plotius Rufus, son of Gaius (IG XII.4.I, 365, 11. I25-6, I70-I).

114 Kokkorou-Alevras 2009: 64 mentions the discovery of a house with Roman features, hypocaust heating, and mosaics, in late Hellenistic Halasarna. See also De Matteis 2004: 63, n. 8 for another mosaic on Cos with parallels in late Republican villae.

115 Georgopoulou 2005 (Aegean); Finkielsztejn 2004 (Levant); Sherwin-White I978: 236 (Black Sea); Empereur and Hesnard I987: 22; Freed and Moore I996: 22; Georgopoulou 2006 (Western Mediterranean); Parker I992: nos 477, 593, 6I 8, 647, II23, I I74, I 206 (shipwrecks).

116 Finkielsztejn 2000: 209-IO; 2004: I6I.

117 Johnsson 2004: I44.

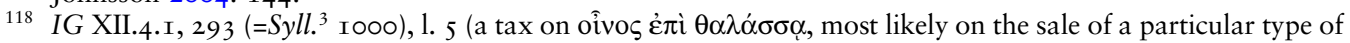
wine), 11. 7-8 (a tax on wine produced on Calymna), and 1. 9 (a tax on either the sale or possession of slaves working in vineyards). Crowther 2004: 25-6 attributed the inscription to a stonecutter, who is otherwise attested in the late second century B.C. 
Mediterranean. We can then only speculate how these Italian viticulturists shaped or changed the production and movement of wine on Cos, and note that their presence appears to have coincided with the peak of Coan production and, interestingly enough, with the decline in the volume of the Rhodian export of wine, which, in late second-century Labraunda at least, was demonstrably replaced by Coan wine. ${ }^{119}$

The history of the perception of Coan wine in Italy points to an additional way in which these men might have transformed the production on the island. In the middle of the second century B.c. Cato knew Coan wine as a good variant of Greek wine - wine mixed with sea water, that is - but for him this was simply the type of wine that one would make to give to the familia working one's estate. ${ }^{120}$ This type of wine was also appreciated for medicinal reasons. ${ }^{121}$ Imitating it thus simply was a matter of good and responsible household management. However, by the late first century B.c. this type of wine was no longer simply known as Coan wine, it was a particular type of it: white Coan wine. ${ }^{122}$ At the same time, people in late Republican Italy also knew different types of Coan wine. Festus, summarizing the work of first-century B.C. grammarian Verrius Flaccus, explains the meaning of vinum hippocoum: it was a wine from a particularly excellent field on Cos called Hippo. ${ }^{123}$ The existence of such local knowledge of the viticultural geography of Cos reveals that in Italy Coan wine had indeed become a high-end product, known for its high quality and drunk in great quantities. ${ }^{124}$ This transformation of the status of Coan wine in Italy is remarkable, and just as in the case of cattle and horses from Epirus, we can speculate whether the involvement of Italians in the production of wine on this island had anything to do with it. By contrast, in the next case study - the Italian exploitation and processing of alum on Melos - the way in which Italians with properties in the provinces shaped local production as well as consumption in Rome and Italy is no longer a matter of speculation. The Italians there arguably put Melian alum on the map; they created it as a product in the western Mediterranean.

\section{Melos}

Like many cities in the Greek East, Melos witnessed the increasing arrival of Italians over the course of the second century B.C. ${ }^{125}$ Grave inscriptions from this period bear Roman

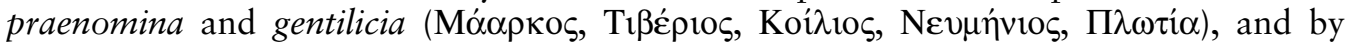
the late first century в.C. Italians, possibly of freedman origin, were setting up altars and stoas on the island. ${ }^{126}$ In the earliest Latin inscription on the island, which dates to the first century B.C., Gaius Caelius Eros, libertus of Gaius, is identified as a mercator, a

\footnotetext{
119 Säflund I980: 9 presents the evidence from Labraunda. On the history of the Rhodian wine trade and its steep decline in the I20S B.C. see Finkielsztejn 200I: especially I94-5; Badoud 20I4: 24. Rauh I999: I75-8 hypothesized that Italian shipping companies began to exclude Rhodians from the Aegean and the western Mediterranean.

120 Cato, Agr. I04-5, I I2-I3 with Moore 2010: 92. Dem., Lacr. 35.32 thinks of Coan wine in an analogous way.

121 Cato, Agr. I 58 . For Coan wine in the Hippocratic corpus see HC VII (Littré): 233, 247.

122 Hor., Sat. 2.4.29 ('vinum Coum album'); Plin., HN I4.77-9 ('vinum leucocoum').

123 Festus, De sign. verb., s.v. 'hippocoum vinum'.

124 For a parallel see Ath. I.32.e-f, who discusses a particular type of Chian wine, its three subcategories and their respective qualities. Note though that in Hor., Sat. 2.8.9 and I 5 only the accumulated dregs of Coan wine could reach the same level of conspicuous consumption as drinking Chian wine. There was still a clear hierarchy between the two. On the plentiful consumption of Chian and Coan wine in Italy see Varro, Rust. 2.pr.3.

125 Mendoni and Zoumbaki 2008; Zoumbaki 20I4a. Note that the people of Melos dedicated a statue to Roma in the middle of the second century B.C. (IG XII.3, I097), which must have been one of the first to be erected in Greece.

126 IG XII.3, I 230 (Plotia, daughter of Marcus), I 233 (Tiberius, Coelius and Numenius), I078 (L. Magius Eros), and 1079 (Magia Pulchra, daughter of L. Magius Eros). For Eros as a name indicating freedman origins, see Mendoni and Zoumbaki 2008: MEL 7, MEL 35.
} 
merchant. ${ }^{127}$ Tantalizing though it may be, this inscription is the only glimpse of the Italians' involvement in the economic life of Melos that the epigraphic evidence provides. Without the unusually intensive and thorough archaeological exploration that the island's landscape has witnessed over the past forty years, the striking transformations in the island's economy that the Italians wrought would have escaped historians completely. ${ }^{128}$

Melos is rich in mineral resources that are exploited to this day. ${ }^{129}$ In ancient times the island was known for its pumice and melinum, Melian earth, but above all for its alum and sulphur deposits. ${ }^{130}$ The astringent qualities of alum and sulphur made them essential ingredients in the production of various goods, including metals, leather, textiles, cosmetics, and pharmaceutical remedies. As Diodorus wrote in relation to similar deposits on Lipari, these minerals were 'of great usefulness'. ${ }^{131}$ So useful, necessary and rare were these minerals that the inhabitants of Lipari could apparently place an exorbitant tax on their export.

During the Classical and Hellenistic periods the inhabitants of Melos exploited the island's mineral resources, alum in particular. Hippocratic authors writing in the fifth and fourth centuries B.c. knew of the island's alum and advised its use in the treatment of wounds and infertility, and so did Bolus of Mendes, who used alum from Melos in his experiments in second-century B.C. Alexandria. ${ }^{132}$ While this exploitation left some traces in the archaeological record, the Roman period witnessed a dramatic increase in the number of sites related to the extraction and processing of mineral resources especially of alum - on the island with close to twenty such sites identified so far. ${ }^{133}$ What is more, the connections between and interdependence of these sites makes it possible to assess the organization of the exploitation of Melian alum in the Roman period.

Sites related to the exploitation of Melian alum in the Roman period fall into three interdependent categories: mineral extraction sites, ceramic production sites, and processing and export sites. ${ }^{134}$ The raw materials from the first type of sites and the pottery produced in the second were then used in the sites of the third type to process the alum that would eventually be exported. ${ }^{135}$ At least five geographical clusters have been identified on the island, each of them including one of all three site-categories. Furthermore, each of these clusters was located in the vicinity of a villa-style building. ${ }^{136}$ Importantly, the connection between these sites does not rely on geographical proximity alone. In at least two cases, pottery from different sites in a cluster shares stamps that are found nowhere else on the island. ${ }^{137}$ The existence of these clusters strongly suggests

\footnotetext{
127 CIL III Suppl. I $4203^{\text {IO }}$.

128 On the archaeological exploration of Melos see Le Quéré 2015a: 307-II, who summarizes the relevant bibliography.

129 On the geology of Melos and the Melian exploitation today see McNulty 2000: 26-45.

130 The mysterious Melian Earth (melinum) was likely to be a combination of silica, alunite and kaolin (McNulty 2000: 60-6, I 56-62).

131 Diod. Sic. 5.I0.2.

132 Hippoc., Ulc. I I.2 I, I 2.4O, I 8.I and Mul. 225.I. For the date of De Ulceribus, see the Budé edition (vol. 8): 25. On the text of Bolus of Mendes see Berthelot and Ruelle [I888]I963, vol. 2: 44I, with Fraser I972: 440-3.

133 Cherry I982b; Karvonis and Mikedaki 2012: I7I-5. On the exploitation of Melian sulphur in Roman times see McNulty and Hall 200I; Le Quéré 20I5a: 3I I-I3.

134 Surveys have uncovered six mineral extraction sites, at least four ceramic production sites, and at least three processing and export sites. For a description of all these sites, their location, and their interdependence see McNulty 2000: I 84-222, 279-89.

135 For a detailed study of one processing site (Aghia Kyriaki) see Photos-Jones et al. I999; Hall et al. 2003.

136 For rural villae in at least eight different locations on the island see Cherry I982b: nos 56, 8I, I00, Io8; Karvonis and Mikedaki 20I2: I7I-5. For the geographical clusters see Le Quéré 20I5a: 3I4-I7; Le Quéré 2OI 5 b: 226-3I.

137 Atkinson and Photos-Jones 200I: 80-I (stamp A); Le Quéré 20 I 5a: 3I3, 3 I 5 (stamp COLO[- -]).
} 
the integration of all aspects of production - from extraction through processing and export - under the control of one individual. The inclusion in these clusters of the villa-style buildings - some of them decorated with Roman cemented pebble mosaics and polychrome marble revetment (at Soleta, Provatas and Agathia) - indicates that some of these individuals were Italians or at least claimed to have a particular relationship with that part of the world. ${ }^{138}$ The amphora stamps on Milo ra amphorae, in which Melian alum was exported, lend further support to this idea. Most of them clearly abbreviated an Italian name. They include COR, CO[- -], [-]OR, PRISCIL, EROT(IS), COLONUS, and TI. CLAVDI SOSISTRATI. ${ }^{139}$ Significantly, these stamps were not only found on amphorae. Stamps reading COLO[- -], COR and CO[- - ] were also found on lekanai at ceramic production sites together with amphorae bearing the same stamp. ${ }^{140}$

The following picture emerges. In the Roman period several members of the Italian diaspora, who - we should assume - owned the natural resources of Melos that they exploited, oversaw separate, but analogous integrated systems of alum production. The fact that at least three of the families were important members of the Melian élite throughout the first, second and third centuries A.D. supports the idea that they owned these resources. ${ }^{141}$ While it is hard to date the emergence of the sites that constituted these systems with any precision, Milo ra amphorae, the type of amphorae most commonly associated with the export of minerals from Melos in the Roman period and that were demonstrably produced at the ceramic production sites on the island, have been found in deposits from the last decades of the first century B.c. in Arles, Milan and Padua. ${ }^{142}$ In Arles the deposit was located next to a tannery that was in operation in the middle of the first century B.C. It would appear, then, that the second half of the first century B.C. presents a likely terminus ante quem for the establishment of at least some of the systems of exploitation that the clusters of sites constituted.

These systems of exploitation that the members of the Italian diaspora introduced constituted an intensification of the production of alum on the island. The dramatic increase of Roman-period sites related to this production, as well as the fact that very little Hellenistic pottery has been found at these sites, suggests as much. ${ }^{143}$ The findspots of Melian amphorae outside of Melos also allow us to speculate that the increased production on the island mainly fed into the production of textiles and leather elsewhere. ${ }^{144}$ In short, the archaeology of Melos clearly shows what the evidence for Epirus and Cos could only hint at: as Italians in the diaspora acquired landed resources, they capitalized on a particular ecological potential of a region and intensified its exploitation, thus fundamentally transforming the economy of the place in question.

Milo ra amphorae have only recently been identified and connected to the production and export of alum from Melos. ${ }^{145}$ As a result, their findspots cannot in any way be taken to be representative of the export of alum from Melos, but they are nonetheless significant for our purposes here. Starting in the first century B.C., these amphorae and the alum that

\footnotetext{
138 While the lack of excavation makes it impossible to give a precise date for these villae, see Mackenzie I 897: 8I-4 for a possible first-century B.C. date for some of them (at Aghia Eleni and Agathia).

139 Raptopoulos 20I4: 33I, 338-40, 356, 360-2, 388-93. Even though the name Eros is a widespread and common one, it is tempting to connect the stamp EROT(IS) with the aforementioned freedman mercator.

140 Raptopoulos 20I4: 360; Le Quéré 20I 5b: 230.

141 On the Eros, Cornelii and Tiberii Claudii on Melos, see Zoumbaki 20I4a: 320-5; Le Quéré 20I5a: 200-2, 238-5I, 265-72, 3I3. We discuss this evidence in further detail below, Section IV and n. I68.

142 Borgard 2005: I64-6; Cipriano et al. 2005: I90-I; Pesavento Mattioli 2005: I77-85.

143 Cherry I982a: I0-23; McNulty 2000: I68-78.

144 For example, Milo ra amphorae were found in artisanal contexts in Milan, Cavaillon, Arles (Borgard 2005: I64-6) and in Padua, where they were most likely linked with the well-known local wool production (Pesavento Mattioli 2005: I80).

145 Picon 200I; Raptopoulos 2005.
} 
they contained made their way to the western Mediterranean - to Italy, to the north in particular, and to southern Gaul, where some of the same Latin stamps were also found. ${ }^{146}$ This is particularly noteworthy because Lipari, situated to the north of Sicily, had plentiful alum deposits that were exploited at the time. In other words, Melos and Lipari did not supply the western and eastern Mediterranean respectively, as has been hypothesized. ${ }^{147}$

Two factors explain this phenomenon. First, just as we argued in the case of Epirote cattle and Coan/Chian wine, the Italians who owned alum resources on Melos and organized their exploitation were seemingly interested in the export and shipping of at least a part of their products. The location of their processing sites, which are all close to natural harbours, ${ }^{148}$ points in this direction, as do several tituli picti that have been found on the necks of their amphorae. It has recently been suggested that these tituli picti pointed out the recipient of the amphora in question. ${ }^{149}$ The Melian amphora with SEPUL written on its neck that was found in Padua, where the Sepulli were a well-known family engaged in various craft activities, is a particularly striking piece of evidence in support of this idea. ${ }^{150}$ In other words, it seems likely that the Italians on Melos acted as connectors, that their relationship with people in and from Italy, rather than the need for minerals, brought the Melian alum to the western Mediterranean.

Second, at least by the first century A.D., Melian alum was not simply any alum. Among the many sources of alum through the empire with which Pliny and Dioscorides were familiar, it was considered the best - the best for tanning, for processing wool, and for medicinal purposes. ${ }^{151}$ These references stand in stark contrast to Diodorus' thinking about Melian alum, who, writing in the middle of the first century в.C., emphasized the Melian deposits' paucity. ${ }^{152}$ In other words, in the western Mediterranean at least, the alum that the Italians on Melos produced became a high-end product. Pliny referred to alum and other Melian minerals as nobilissimum, laudatissimum and optimum ex omnibus, adjectives that nicely capture the intertwining of the product's quality and its consumer's social standing. Melian alum thus presents yet another case in which the Italians in the diaspora engaged in the production and marketing of goods that helped people in the imperial centre transform economic change into social difference. The Italians, we suggest, were involved in the making of such high-end goods - not only physically on the ground in the provinces but also as regards their reputation in Italy.

\footnotetext{
146 Findspots include Padua, Oderzo, Iulia Concordia, Aquileia, Este, Cremona, Milan, Chieri, Vercelli, Turin and Novara in northen Italy; Arles and Cavaillon in the lower Rhône Valley; Kition on Cyprus. For references and a map presenting the distribution of the finds see Le Quéré 201 5a: 322-3.

147 Borgard 2005: 167.

148 McNulty 2000: 282-3 demonstrates that the processing sites, all coastal, could provide shelter and were in all likelihood also used to export the minerals off the island and to receive supplies and raw materials for the processing of the minerals.

149 Pesavento Mattioli 2005: I 82-4; Cipriano et al. 2005: I 89. No tituli picti on amphorae were found on Melos: this, and the fact that the tituli picti are rather hastily drawn, may be a clue that they were written during the exportation process or for the redistribution of the amphorae once they had reached the port of destination.

150 A member of the gens Sepullia was officinator in Padua (CIL V 2885 with Buchi I987: I 59); stamps with the names of members of this family were found on olive oil amphorae Dressel $6 \mathrm{~B}$ that were widespread in northern Italy (Cipriano and Mazzocchin 2000: 175-6).

151 Plin., HN 35.52.1 84 and I88, 35.19.37; Diosc., Mat. Med. 5.I 23.

152 Diod. Sic. 5.IO.2. On the possibility that Diodorus takes over Timaeus' remarks here see most recently Champion 2016: Fi64.
} 


\section{DISCUSSION}

The economic lives of Italians in the diaspora included a great many things: they were slavers, managing the sale and movement of Roman armies' captives; ${ }^{153}$ they were art dealers, acting as middle-men between Greek production and Italian tastes; ${ }^{154}$ they were also actors, catering, in part at least, to the tastes of Italians abroad. ${ }^{155}$ We have argued here that landholding and involvement in local production were not exceptional among these Italians, but should be considered the norm along with the provision of credit and the movement of people and goods. Although the evidence is not always straightforward, it seems likely that the widespread nature of Italian landownership that we have diagnosed in the late Republic should also be imagined elsewhere in the Greek East and in other parts of the empire. ${ }^{156}$ As a result, Italian landholding in the provinces, which is so familiar to scholars of the imperial period, has a distinct and significant pre-history in the late Republic.

The evidence from this earlier period also suggests that these landholders were much more socially diverse than imperial sources, which mostly concern senators, would lead us to believe. These blind spots in scholarship on both sides of the republican-imperial divide are no accident. They reflect a significant but under-appreciated moment in the history of Italian, and more generally Roman, landownership in the provinces - the moment, most likely part of Augustus' social legislation, when land in the provinces began to count for the census evaluation of Roman citizens. ${ }^{157} \mathrm{~A}$ far-reaching change in the political economy of the empire, which probably provoked another wave of Roman land-grabbing in the provinces, this reform, and the patterns of evidence that it produced, should not lead us to obfuscate the early days of Italian landholding in the provinces. The figure of the vilicus/oikovómos that imperial inscriptions from Anatolia attest so frequently already featured in the province of Asia as Cicero knew it. ${ }^{158}$

In these early days, then, members of the diaspora exploited their landholdings in a variety of ways, leasing them out, for example, or growing grain. ${ }^{159}$ At the same time, our case studies reveal a distinct pattern of exploitation, a particular strategy that several Italian landowners pursued. Focused on the production of high-end goods with a view to marketing at least some of these goods in Italy and Rome, these Italians appear to have followed the same economic and socio-political imperatives that underpinned

\footnotetext{
153 Hatzfeld I9I9: 223; Thonemann 20I0: I72-3.

154 Hatzfeld I9I9: 227-30; Rawson I975; Wallace-Hadrill 2008: 426-7.

155 Hatzfeld I9I9: 23 I.

156 In Spain and Africa Caesar's Civil Wars reveal groups of landowners: [Ps.-Caes.], B Afr. 36.2 and Caes., B Civ. I.86. There is no trace in Cicero's Pro Quinctio that the defendant's properties in Gallia Narbonensis were a surprise to the trial's audience.

157 For the ban on declaring provincial estates in the late Republic see n. 35 above. Later emperors' efforts to oblige senators to have properties in Italy (Plin., Ep. I.I9.4 and SHA, Marc. II.8) make no sense unless this ban had been lifted. The context of Augustus' social legislation seems likely since the first-century A.D. wax tablets recording copies of the census declarations of Roman citizens in Egypt all state that the declarations were made according to the Lex Aelia Sentia and the Lex Papia Poppaea of A.D. 4 and 9 respectively (Schulz I942 and I943).

158 Cic., Flac. 88 (cf. Table I, no. 20). See Corsten 201 6: 266-8; Christol 2016: 280-1 for the Greek renderings of vilicus and the activities of these agents in the imperial period. Examples of imperial inscriptions mentioning vilici include SEG 37, I087 (Pontus), IGR 4.895 (Pisidia), and CIL III 337 (Bithynia).

159 M. Feridius leased his holdings in Cilicia to the cities in which they were located (Table I, no. II with Shackleton Bailey I977: 395, who cites Cic., Fam. I3.76 as a parallel for this practice in Italy). It also seems likely that Italians in Phrygia not only pastured sheep, but also contributed to the increased cultivation of grain that the Anatolian plateaus witnessed from the second century B.C. onwards (Mitchell I993: I, 242-6). On the complementarity of grain and pastoralism in the region see Dio Chrys., Or. 35.16 and Corsten 2005: no. I3. For the different types of grains (mostly wheat and barley) cultivated in Bithynia, Phrygia and Cappadocia, see Gal., De alim. fac. I.9.ı0, I.ı3.6-I8. We can really only speculate what Pompey's veterans did with their holdings.
} 
pastio villatica - the cultivation of high-end food items for the Roman dinner table in the suburbium of Rome and in the Bay of Naples - on an empire-wide scale. ${ }^{160}$ Rome and other Italian cities, the inhabitants of which were eager to join the Roman élite in consuming empire, provided stable markets and high returns for high-end goods from the provinces. At the same time, Italy and Rome were precisely the places where, just as their fellow Romans and Italians, they would hope to put their products and productivity on display - something that their contemporaries often did in the context of their villae. ${ }^{161}$

This perspective reveals these Italian landowners as entrepreneurs, which they are often called, only to the extent that, just as for their modern counterparts, the rules of the game that they were playing were firmly set. The goals of this game, though, were not limited to maximizing income. As we have seen, several Italian landowners in the provinces were equestrians, and others probably had the land that would have allowed them to join that group had it not been located in the provinces. While rarely aspiring to a career in politics, these men focused on producing and marketing goods that allowed them to claim a place in the society of the imperial centre. Some negotiatores, Cicero suggests, staged their return to Italy on the model of the reditus of a Roman magistrate, with large crowds in attendance. ${ }^{162}$

The diagnosis of this economic and socio-political strategy makes it possible to posit further places that became 'outposts of the demographic and economic dynamics' that Roman imperialism created in analogous ways to Epirus, Cos and Chios, and Melos. Phrygia, and in particular the Lycus valley, seems a prime candidate. While Italians, both as individuals and as collectivities, are already attested in Phrygia in the early first century B.C., there is no direct evidence for Italian landholding at the time. ${ }^{163}$ That being said, Stephen Mitchell has shown that members of Italian families that we know owned land in Phrygia in the first three centuries A.D. were already present in the late Republican period. ${ }^{164}$ Importantly, cities in the area of the Lycus valley - the towns of Laodicea, Hierapolis, Philadelphia, Colossai, and possibly Acmonea, that is - saw an analogous reshaping of their ecological potential to the one we found in our three case studies. While Phrygia was previously known for textile-production, a passage from Strabo suggests that the wool and fabrics of the Lycus valley only became famous as high-end products - as even finer than Milesian wool, the epitome of luxury since the Archaic period, Strabo and Pliny claim - in the late second and early first centuries B.c. ${ }^{165}$ To us, at least, the coincidence of this change in local textile production with Italian presence and possible landownership in the area suggests that the origins of the Lycus-valley region as the most important centre for textile production in the eastern Mediterranean quite possibly lay with the particular economic and socio-political strategies that members of Rome's imperial diaspora regularly pursued. ${ }^{166}$

Locally, in the places where these Italians had their landholdings, these strategies meant displacement, changing economic landscapes, and the disruption of previous ways of life their behaviour constituted fractals of Roman imperialism, one might say - with local variations, of course. While on Cos the Italians joined in an already flourishing

160 On pastio villatica and the transformation of the Roman suburbium see Morley I996: especially 83-107.

161 On this culture of agricultural display in Italy see e.g. Purcell I995: I 5 I-4, I 57-6I; Bodel I997.

162 Cic., Pis. 55.

163 On this Italian diaspora in Phrygia, see more generally and most recently Thonemann 20I0: I69-7I; 20II: 99-IOI; 20I3: 29-3 I; Avram 2016.

164 Mitchell I979: I3; I993: I, I 5 I, I 58-62; Thonemann 2010: I73. First-century B.c. landholdings in Apollonis and Thyateira - cf. Table I, nos 2, I2, I5, I 8 - increase the plausibility of this argument.

165 Strabo I2.8.I3 and I6; Plin., HN 8.73. On Milesian wool and its reputation see e.g. Ath. I 2.5 I9b and 540d; Chandezon 2003: 40I-2. On Phrygian textiles see Virg., Aen. 3.483-5; Ov., Met. 6.6r6; Plaut., Men. 426, 469, 563, 6I 8, 68I where one of the characters takes a mantle to Phrygio, the embroiderer.

166 Pleket I988: 33-5; Thonemann 20II: I86-90; Benda-Weber 2013. 
production of wine and, just as in Messene, owned a portion of the estates in the city, in Melos they and their agents appear to have completely taken over the ownership and exploitation of mineral resources on the island. Similarly, the dramatic disruption of previous ways of life that the Roman villa at Agios Donatos built on the site of a Hellenistic fort symbolizes does not need to be imagined on the Aegean islands.

On a different level, Italian landholdings spelt changes for the Greek cities in which they were located. In principle, land in these cities was the basis of political power, and Italians with landholdings there began to participate in civic life. The alum-producing Italians on Melos who held civic offices on the island are one example of this phenomenon. ${ }^{167}$ At the same time, several Italians owned land in more than one city - a circumstance that made them less dependent on individual ones, while also increasing their power in relation to each. The fact that Nicias Curtius, who became tyrant of Cos in the middle of the first century B.C., was a freedman of one of the Italians producing wine on the island, who also had several properties in other cities in the region, is a good illustration of just that dynamic. ${ }^{168}$

However, not only the patterns of Italian landholdings, but also Italian economic strategies might have posed new challenges for the idealized, but unobtainable autonomy of Greek cities. A second-century B.C. decree from Abdera that granted M. Vallius the right to export one hundred medimnoi of grain per year for his private use might reveal a glimpse of the potential conflict between local concerns with the food supply and export-eager Italians interested in highly specialized production. ${ }^{169}$ While there certainly existed various local ways of negotiating these conflicts, it seems likely that the Italians' particular strategies of exploitation further exacerbated the dependency of the communities in which their estates were located, providing yet again opportunities for Italians to take on rôles locally. In short, if Italians exploited their estates in part at least with a view to markets and audiences in Rome and Italy, the fact of landholding and these particular strategies of exploitation also got them involved in politics locally. Atticus seems to have practised such politics, both in Buthrotum and on Corcyra. ${ }^{170}$

Lastly, we would like to suggest that in addition to raising new questions about the history of ownership and exploitation of Italian landholdings in the provinces and how to explain it, our arguments here also have implications for how the Roman Empire fits into the history of empire and imperialism more generally. Arguably, the widespread nature of Italian landholding and involvement in primary production that we have sought to establish, make Roman imperialism in the late Republic look more similar to the imperialisms of early modern Britain or of the Dutch Republic, where diasporic landholding and plantation agriculture have long dominated the picture, than it has ever done before. Teasing out and explaining the similarities and differences between these cases - whether they concern the types of goods produced, the relationship of the imperial diaspora to imperial power and institutions, or the diaspora's relationship and attitude towards local populations - now appear as intriguing research problems. Admittedly, the comparison between modern empires and the Roman case has a long and problematic history, being often carried out by nineteenth- and early twentieth-century imperial administrators themselves. The perspective that we propose the perspective of comparative expropriation, one might say - we hope can escape the

\footnotetext{
167 In the first and second centuries A.D., only people with Roman or 'romanizing' names are attested as holding political or religious offices on Melos (Le Quéré 20 I 5a: 238). Among them were L. Cornelius Domitianus and his daughter Cornelia Domitia (IG XII.3, I I I 8) and Tib. Claudius Frontonianus (IG XII.3, I I I9), all most likely related to the Cornelii and Claudii that appear on Melian amphora stamps. On these Italian families see n. 142 above.

168 See n. I03 above.

169 Loukopoulou et al. 2005: 202-4 (no. E8). On Italians at Abdera see now Papaioannou 20 IO.

170 Cic., Att. 4.8.I.
} 
pitfalls of this tradition and contribute to refining our understanding of the Roman case and of modalities of empire and imperialism more generally.

University of Tübingen, Germany (L. P. E.)

lisa.eberle@uni-tuebingen.de

University of Rouen-Normandie, France (E. L. Q.)

enora.le-quere@univ-rouen.fr

\section{BIBLIOGRAPHY}

Alcock, S. E. I989: 'Roman imperialism in the Greek landscape', Journal of Roman Archaeology 2, 5-34

Alcock, S. E. I993: Graecia Capta. The Landscapes of Roman Greece, Cambridge

Alcock, S. E. 2007: 'The Eastern Mediterranean', in Scheidel et al. 2007, 67I-98

Atkinson, J. A., and Photos-Jones, E. 200I: 'A site with "special purpose": mining activity on Melos in the late Roman period', in Fell et al. 200I, 77-85

Avram, A. 2016: 'Propriétaires et citoyens à Dorylaion: enquête sur les citoyens romains et les villages sur le territoire', in Lerouxel and Pont 2016, 87-1 I0

Badoud, N. 20I4: 'The contribution of inscriptions to the chronology of Rhodian amphora eponyms', in P. Guldager Bilde and M. L. Lawall (eds), Pottery, Peoples and Places. Study and Interpretation of Late Hellenistic Pottery, Aarhus, I7-28

Benda-Weber, I. 20I3: 'Textile production centres. Products and merchants in the Roman province of Asia', in M. Gleba and J. Pásztókai-Szeöke (eds), Making Textiles in Pre-Roman and Roman Times: People, Places, Identities, Oxford, I69-9 I

Benoit, F. I956: 'Épaves de la côte de Provence. Typologie des amphores', Gallia I4.I, 23-34

Berthelot, M., and Ruelle, C.-E. [1888] I963: Collection des anciens alchimistes grecs, Paris

Bertrand, A., and Botte, E. 20I 2: 'La présence romaine en Dalmatie méridionale (de la fin de la République au Haut-Empire). Premières approches pour une étude de l'exploitation économique des territoires', in Marion and Tassaux 20I2, I77-85

Besonen, M. R., Rapp, G., and Jing, Z. 2003: 'The Lower Acheron River Valley: ancient accounts and the changing landscape', in Wiseman and Zachos 2003, I99-263

Bleicken, J. I974: 'In provinciali solo dominium populi romani est vel Caesaris. Zur Kolonisationspolitik der ausgehenden Republik und frühen Kaiserzeit', Chiron 4, 359-4I4

Bloch, M. [1954] 2004: The Historian's Craft, Manchester

Bodel, J. I997: 'Monumental villas and villa monuments', Journal of Roman Archaeology I0, 5-35

Borgard, P. 2005: 'Les amphores à alun (Ier siècle avant J.-C.-IVe siècle après J.-C.)', in Borgard et al. 2005, I 57-69

Borgard, P., Brun, J.-P., and Picon, M. (eds) 2005: L'alun de Méditerranée, Collection du Centre Jean Bérard 23, Naples/Aix-en-Provence

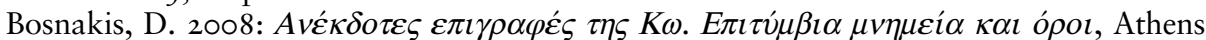

Bouchon, R. 2007: 'Les "porteurs de toge" de Larissa', Topoi I 5, 25 I-84

Bowden, W. 2003: Epirus Vetus: The Archaeology of a Late Antique Province, London

Bowden, W. 2009: 'Thesprotia in the context of Roman and late antique Epirus', in Forsén 2009, I $67-84$

Bowden, W., and Përzhita, L. 2004: 'Archaeology in the landscape of Roman Epirus: preliminary report on the Diaporit excavations, 2002-3', Journal of Roman Archaeology I7, 4I 3-33

Brélaz, C. 2016: 'Des communautés de citoyens romains sur le territoire des cités grecques: statut politico-administratif et régime des terres', in Lerouxel and Pont 2016, 69-85

Broughton, T. R. S. I938: 'Roman Asia Minor', in T. Frank (ed.), An Economic Survey of Ancient Rome. Vol. 4, Baltimore, 499-916

Bruneau, P. I988: 'Deliaca VII', Bulletin de Correspondance Hellénique I I 2.2, 569-82

Brunt, P. I97I: Italian Manpower (225 B.C.-A.D. I4), Oxford

Brunt, P. I988: 'The equites in the late Republic', in P. Brunt, The Fall of the Roman Republic and Related Essays, Oxford/New York, I44-93 
Buchi, P. I987: 'Asseto agrario, risorse e attività economiche', in E. Buchi (ed.), Il Veneto nell'età romana, I. Storiografia, organizzazione del territorio, economia e religione, Verona, I03-84

Cabanes, P. I976: L'Épire, de la mort de Pyrrhos à la conquête romaine (272-167 av. J.-C.), Paris

Cabanes, P. (ed.) I987: L'Illyrie méridionale et l'Épire dans l'Antiquité. I, Clermont-Ferrand

Callender, M. H. I965: Roman Amphorae, with Index of Stamps, London

Carre, M.-B., Monsieur, P., and Pesavento Mattioli, S. 20I4: 'Transport amphorae Lamboglia 2 and Dressel 6A: It and/or Dalmatia? Some clarifications', Journal of Roman Archaeology 27, 4I $7-28$

Cassola, F. I970-7I: 'Romani e Italici in Oriente', Dialoghi di Archeologia 4-5, 305-22

Čašule, N. 20I 2: “'In part a Roman sea”: Rome and the Adriatic in the third century B.c.', in C. Smith and L. M. Yarrow (eds), Imperialism, Cultural Politics, and Polybius, Oxford, 205-29

Ceka, N. 1987: 'Le koinon des Bylliones', in Cabanes 1987, I35-49

Champion, C. B. 2016: 'Timaios (566)', in I. Worthington (ed.), Brill's New Jacoby, Brill Online available from <http://brillonline.nl/entries/brill-s-new-jacoby/timaios-566-a 566>

Chandezon, C. 2003: L'élevage en Grèce (fin Ve-fin Ier s. a.C.): l'apport des sources épigraphiques, Scripta Antiqua 5, Bordeaux

Cherry, J.-F. I982a: 'Appendix A: Register of archaeological sites on Melos', in Renfrew and Wagstaff I982, 29I-309

Cherry, J.-F. I982 b: 'A preliminary definition of site distribution on Melos', in Renfrew and Wagstaff I 982 , IO-23

Christol, M. 2016: 'Les domaines des Claudii Seueri en Asie Mineure', in Lerouxel and Pont 2016, $275-88$

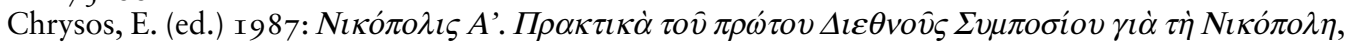
Preveza

Cipriano, S., and Mazzocchin, S. 2000: 'Considerazioni su alcune anfore Dressel 6B bollate. I casi di VARIPACCI e PACCI, APICI e APIC, P. Q. SCAPVLAE, P. SEPVLLI P. F. e SEPVLLIVM', Aquileia Nostra 7I, I49-92

Cipriano, S., Mazzocchin, S., De Vecchi, G., and Zanco, A. 2005: 'Le anfore ad impasto grezzo rinvenute nella Venetia: tipologia, cronologia, distribuzione, caratteri chimico-petrografici e tecnologia di produzione', in Borgard et al. 2005, I87-96

Corsten, T. 2005: 'Estates in Roman Asia Minor: the case of Kibyratis', in S. Mitchell and C. Katsari (eds), Patterns in the Economy of Roman Asia Minor, Swansea, I-5 I

Corsten, T. 20ı6: 'Bauer und Bürger: Einflußmöglichkeiten von Landbesitzernauf das städtische Leben im kaiserzeitlichen Kleinasien', in Lerouxel and Pont 20I6, 26I-74

Cottier, M., Crawford, M., Crowther, C., Ferrary, J.-L., Levick, B. M., Salomies, O., and Wörrle, M. (eds) 2008: The Customs Law of Asia, Oxford

Crowther, C. 2004: 'The dating of Koan Hellenistic inscriptions', in Höghammar 2004, 2I-60

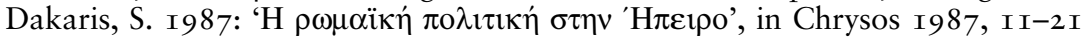

D’Alessandro, L., and Sebastiani, R. 20 I 2: 'Le vin de l'Adriatique à Rome: les témoignages du Nuovo Mercato Testaccio', in Marion and Tassaux 20I2, 479-8 5

Delplace, C. I977: 'Publicains, trafiquants et financiers dans les provinces d'Asie Mineure sous la République', Ktema 2, 233-52

De Matteis, L. M. 2004: Mosaici di Cos, dagli scavi delle missioni italiane e tedesche (1900-1945), Athens

Deniaux, É. I987: 'Atticus et l'Épire', in Cabanes I987, 245-54

Deniaux, É. I993: Clientèles et pouvoir à l'époque de Cicéron, CEFR I 82, Rome

Desy, P. I989: Les Timbres amphoriques de l'Apulie républicaine. Documents pour une histoire économique et sociale, BAR International Series 554, Oxford

Diaz Fernandez, A. 20I I: 'L. Culleolus proconsul: Cic., Fam. XIII, 4I-42', Latomus 70, 664-75

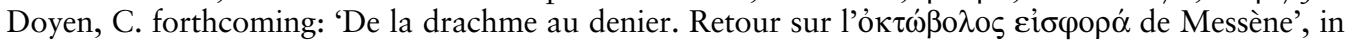

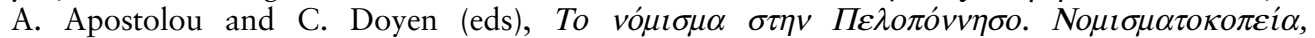

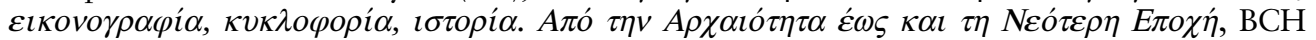
Suppl., Athens

Eberle, L. 2016: 'Law, empire, and the making of Roman estates in the provinces during the late Republic', Critical Analysis of Law 3.I, 50-69

Eberle, L. forthcoming: 'Making Roman subjects. Citizenship in the time of Augustus', Transactions of the American Philological Association $\mathbf{1} 47.2$ 
Empereur, J.-Y. I982: 'Les anses d'amphores timbrées et les amphores: aspects quantitatifs', Bulletin de Correspondance Hellénique I06.I, 219-33

Empereur, J.-Y., and Hesnard, A. I987: 'Les amphores hellénistiques', in P. Lévêque and J.-P. Morel (eds), Amphores hellénistiques et romaines II, Centre des Recherches d'Histoire Ancienne 70, Paris, IO-54

Erdkamp, P., Verboven, K., and Zuiderhoek, A. (eds) 201 5: Ownership and Exploitation of Land and Natural Resources in the Roman World, Oxford

Errington, R. M. I988: 'Aspects of Roman acculturation in the East under the Republic', in P. Kneissl and V. Losemann (eds), Alte Geschichte und Wissenschaftsgeschichte. Festschrift für Karl Christ zum 65, Darmstadt, I $40-57$

Étienne, R. 2002: 'Introduction', in Müller and Hasenohr 2002, I-8

Étienne, R. 2005: 'Hippotrophia: aspects sociaux de l'élevage des chevaux en Grèce', in A. Gardeisen (ed.), Les équidés dans le monde méditerranéen antique, Lattes, 243-48

Étienne, R., Müller, C., and Prost, F. 20I4: Archéologie historique de la Grèce antique (3rd edn), Paris

Fell, J. E., Nicolaou, P. D., and Xydous, G. (eds) 200I: 5th International Mining History Congress. Book of Proceedings, Milos

Ferrary, J.-L. I99I: 'Le statut des cités libres dans l'empire romain à la lumière des inscriptions de Claros', Comptes Rendus des Séances de l'Académie des Inscriptions et Belles-Lettres I35.3, $557-77$

Feuvrier-Prévotat, C. I989: 'Negotiator et mercator dans le discours cicéronien: essai de définition', Dialogues d'Histoire Ancienne 7, 367-405

Finkielsztejn, G. 2000: 'Amphores importées au Levant à l'époque hellénistique', in S. Drougou (ed.),

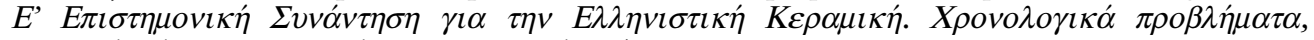

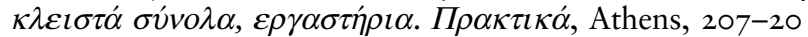

Finkielsztejn, G. 200I: 'Politique et commerce à Rhodes au IIe siècle a.C.: le témoignage des exportations d'amphores', in A. Bresson and R. Descat (eds), Les cités d'Asie Mineure occidentale au IIe siècle a.C., Bordeaux, I $8 \mathrm{I}-96$

Finkielsztejn, G. 2004: 'Koan amphorae imported in the southern Levant in the Hellenistic period', in Höghammar 2004, I 53-64

Finkielsztejn, G. 2006: 'P. Vedius Pollio, producteur de vin à Chios et Cos et fournisseur d'Hérode le Grand', in D. Długosz (ed.), Grecs, Juifs, Polonais: à la recherche de l'origine de la civilisation européenne, Paris, I23-39

Finley, M. I98I: 'Technical innovation and economic progress in the ancient world', in R. P. Saller and B. Shaw (eds), Economy and Society in Ancient Greece, London, I76-95

Finley, M. I999: The Ancient Economy. Updated Edition with a Foreword by Ian Morris, Berkeley/ Los Angeles/London

Follet, S. 2002: 'Les Italiens à Athènes (IIe s. av. J.-C.-Ier s. apr. J.-C.)', in Müller and Hasenohr 2002, 79-88

Forsén, B. (ed.) 2009: Thesprotia Expedition I. Towards a Regional History, Papers and Monographs of the Finnish Institute at Athens I 5 , Helsinki

Forsén, B. 20II: 'The emerging settlement patterns of the Kokytos valley', in Forsén and Tikkala 2OII, I-38

Forsén, B., and Reynolds, P. 20I I: 'An early closed deposit at the Roman villa of Agios Donatos', in Forsén and Tikkala 20I I, 247-68

Forsén, B., and Tikkala, E. (eds) 20II: Thesprotia Expedition II. Environment and Settlement Patterns, Papers and Monographs of the Finnish Institute at Athens I6, Helsinki

Fournier, J. 20I0: Entre tutelle romaine et autonomie civique: l'administration judiciaire dans les provinces hellénophones de l'Empire romain (I 29 av. J.-C.-235 apr. J.-C.), BEFAR 34I, Athens

Frank, T. I933: An Economic Survey of Ancient Rome. Vol. I: Rome and Italy of the Republic, Baltimore

Fraser, P. M. I972: Ptolemaic Alexandria, Oxford

Freed, J., and Moore, J. I996: 'New observations on the earliest Roman amphoras from Carthage: Delattre's first amphora wall', CEDAC Carthage Bulletin I 5, I9-28

Garlan, Y. I993: ‘À qui étaient destinés les timbres amphoriques grecs ?’, Comptes Rendus des Séances de l'Académie des Inscriptions et Belles-Lettres, I 8 I-90

Garozzo, B. I999: 'Nuovi bolli anforari dalla Sicilia occidentale (Entella, Erice, Segesta)', ASNP Quaderni I, 28I-383 
Georgopoulou, V. 2005: 'The dissemination of transport amphorae from Cos. A contribution to the study of the Coan trade in the Eastern Mediterranean during the Hellenistic period', in M. Berg Briese and L. E. Vaag (eds), Trade Relations in the Eastern Mediterranean from the Late Hellenistic Period to Late Antiquity: The Ceramic Evidence, Odense, 179-83

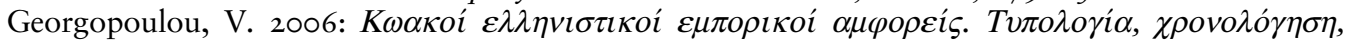
$\delta i \alpha \sigma \pi \sigma \rho \alpha \dot{\alpha}$, unpub. $\mathrm{PhD}$ thesis, University of Athens

Grace, V. R. 1966: 'Stamped amphora handles: the Benachi Collection', Archaeology 19, 286-88

Grandjean, C. 2003: Les Messéniens de 370/369 au Ier siècle de notre ère. Monnayages et histoire, BCH Suppl. 44, Athens

Grandjean, C. (ed.) 2008: Le Péloponnèse d'Épaminondas à Hadrien, Bordeaux

Greco, A. 2003: 'Zagros pastoralism and Assyrian imperial expansion: a methodological approach', in G. B. Lanfranchi, M. Roalf and R. Rollinger (eds), Continuity of Empire(?): Assyria, Media and Persia, Padova, 65-78

Greene, K. 1986: The Archaeology of the Roman Economy, Berkeley/Los Angeles

Greene, K. 2006: 'Archaeological data and economic interpretation', in P. F. Bang, M. Ikeguchi and H. G. Ziche (eds), Ancient Economies, Modern Methodologies: Archaeology, Comparative History, Models and Institutions, Bari, I09-36

Gsell, S. I9I4: Histoire ancienne de l'Afrique du Nord, vol. VII, Paris

Hall, A. J., Photos-Jones, E., McNulty, A. E., Turner, D., and McRobb, A. 2003: 'Geothermal activity at the archaeological site of Aghia Kyriaki and its significance to Roman industrial mineral exploitation on Melos, Greece', Geoarchaeology: An International Journal I 8.3, 333-57

Halstead, P. 1987: 'Traditional and ancient rural economy in Mediterranean Europe: plus ça change?', The Journal of Hellenic Studies 107, 77-87

Hatzfeld, J. I919: Les trafiquants italiens dans l'Orient hellénique, Paris

Hatzfeld, J. I945: La Grèce et son héritage, Paris

Helly, B. I983: 'Les Italiens en Thessalie au IIe et au Ier av. J.-C.', in Les "bourgeoisies” municipales italiennes aux Ile et Ier siècles av. J.-C., Paris/Naples, 35 5-80

Hermann, P. 1959: Neue Inschriften zur historischen Landeskunde von Lydien und angrenzenden Gebieten, Vienna

Höghammar, K. (ed.) 2004: The Hellenistic Polis of Kos. State, Economy and Culture, Uppsala

Horden, P., and Purcell, N. 2000: The Corrupting Sea. A Study of Mediterranean History, Oxford

Jing, Z., and Rapp, G. 2003: 'Coastal evolution of the Ambracian embayment', in Wiseman and Zachos 2003, I 57-98

Johnsson, H. 2004: 'The export of wine to the south-eastern Mediterranean area during the Hellenistic period', in Höghammar 2004, I33-5 I

Karvonis, P., and Mikedaki, M. 201 2: Tabula Imperii Romani. J 35 - Smyrna. I: Aegean Islands, Athens

Kay, P. 2014: Rome's Economic Revolution, Oxford

Kirbihler, F. 2007a: 'Die Italiker in Kleinasien, mit besonderer Berücksichtigung von Ephesos (I 33 v. Chr.-I Jh. n. Chr.)', in M. Meyer (ed.), Neue Zeiten - Neue Sitten. Zu Rezeption und Integration römischen und italischen Kulturguts in Kleinasien, Vienna, I9-36

Kirbihler, F. 2007b: 'P. Vedius Rufus, père de Vedius Pollio', Zeitschrift für Papyrologie und Epigraphik I60, 26I-7I

Kirbihler, F. 20I 6: Des Grecs et des Italiens à Éphèse. Histoire d'une intégration croisée (133 a.C.-48 p.C.), Scripta Antiqua 88, Bordeaux

Kirbihler, F. 20I7: 'Les problèmes d'une mission publique entre République et Empire: P. Vedius Pollio en Asie', in L. Cavalier, F. Delrieux and M.-C. Ferriès (eds), Auguste et l'Asie Mineure, Bordeaux, I $29-52$

Kokkorou-Alevras, G. 2009: 'Der antike Demos von Halasarna auf Kos: vorläufiger Bericht über die Ergebnisse der Ausgrabungen und des Surveys', in C. Reinholdt and P. Scherrer (eds), Aiakeion. Beiträge zur klassischen Altertumswissenschaft zu Ehren von Florens Felten, Vienna, 59-65

Kornemann, E. I900: s.v. 'conventus', RE. IV.I, II73-2000

Lanauro, A. 20I6: 'Finley and the ancient economy', in D. Jew, R. Osborne and M. Scott (eds), M. I. Finley: An Ancient Historian and his Impact, Cambridge, 227-49

Lawall, M. 2005: 'Amphoras and Hellenistic economies: addressing the (over)emphasis on stamped amphora handles', in Z. Archibald, J. Davies and V. Gabrielsen (eds), Making, Moving, and Managing. The New World of Ancient Economies, 323-3I BC, Oxford, I88-232

Le Quéré, E. 20I 5 a: Les Cyclades sous l'Empire romain. Histoire d'une renaissance, Rennes 
Le Quéré, E. 2015b: 'The "opportunistic exploitation" of Melos: a case study of economic integration and cultural change in the Roman Cyclades', in S. T. Roselaar (ed.), Processes of Cultural Change and Integration in the Roman World, Leiden/Boston, 222-38

Lerouxel, F., and Pont, A.-V. (eds) 20I6: Propriétaires et citoyens dans l'Orient romain, Scripta Antiqua 84, Bordeaux

Lévêque, P. 1957: Pyrrhos, BEFAR I85, Paris

Lindhagen, A. 2009: 'The transport amphoras Lamboglia 2 and Dressel 2A revisited', Journal of Roman Archaeology 22, 83-108

Lindhagen, A. 20I3: 'The freemen milieus at Delos and Narona. New perspectives on the Lamboglia 2 wine trade', in A.-L. Schallin (ed.), Perspectives on Ancient Greece. Papers in Celebration of the 6oth Anniversary of the Swedish Institute at Athens, Stockholm, 23 I-50

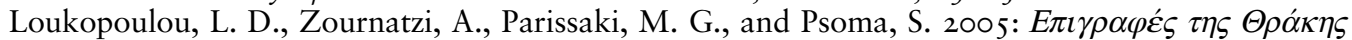

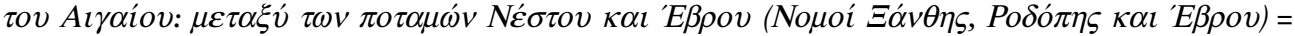
Inscriptiones antiquae partis Thraciae quae ad ora Maris Aegaei sita est (praefecturae Xanthes, Rhodopes et Hebri), Athens

Mackenzie, D. I 897: 'Ancient sites in Melos', Annual of the British School at Athens 3, 7 I-88

MacKinnon, M. 2004: Production and Consumption of Animals in Roman Italy: Integrating the Zooarchaeological and Textual Evidence, JRA Suppl. 54, Portsmouth

MacKinnon, M. 2015: 'Changes in animal husbandry as a consequence of developing social and economic patterns from the Roman Mediterranean context', in Erdkamp et al. 20I 5, 249-74

MacMullen, R. 2000: Romanization in the Time of Augustus, New Haven

Magie, D. I950: Roman Rule in Asia Minor: to the End of the Third Century after Christ, Princeton

Manacorda, D. 1989: 'Le anfore dell'Italia repubblica: aspetti economici e sociali', in Amphores romaines et histoire économique. Dix ans de recherches, CEFR I I4, Paris/Rome, 443-67

Manacorda, D., and Panella, C. I993: 'Le anfore', in W. V. Harris (ed.), The Inscribed Economy. Production and Distribution in the Roman Empire in the Light of Instrumentum Domesticum, JRA Suppl. 6, Portsmouth, 55-64

Marek, C. 2006: Die Inschriften von Kaunos, Vestigia, Beiträge zur alten Geschichte 35, Munich

Marion, Y., and Tassaux, F. (eds) 20I2: Adri Atlas et l'bistoire de l'espace adriatique du VIe s. a.C. au VIIIe s. p.C., Scripta Antiqua 79, Bordeaux

Marshall, A. J. I969: 'Romans under Chian law', Greek, Roman, and Byzantine Studies ı0.3, $255-7 \mathrm{I}$

McCabe, D. F. I986: Chios Inscriptions. Texts and List, Princeton

McNulty, A. E. 2000: Industrial Minerals in Antiquity: Melos in the Classical and Roman Periods, unpub. PhD thesis, University of Glasgow

McNulty, A. E., and Hall, A. J. 200I: 'Divine Theion: the exploitation of sulphur in Melos and Italy', in Fell et al. 200I, 86-9I

Mendoni, L. G., and Zoumbaki, S. 2008: Roman Names in the Cyclades. Part I. MEAETHMATA 56, Athens

Migeotte, L. 2008: 'L'organisation de l'oktobolos eisphora de Messène', in Grandjean 2008, 229-45

Mitchell, S. I979: 'R.E.C.A.M. notes and studies No. 5. A Roman family in Phrygia', Anatolian Studies 29, I3-22

Mitchell, S. I993: Anatolia: Land, Men, and Gods in Asia Minor. Vol. I: The Celts in Anatolia and the Impact of Roman Rule, Oxford

Moore, J. 20I0: 'When not just any wine will do ...? The proliferation of Coan-type wine and amphoras in the Greco-Roman world', Marburger Beiträge zur Antiken Handels-, Wirtschaftsund Sozialgeschichte 28, 89-I 22

Morley, N. 1996: Metropolis and Hinterland. The City of Rome and the Italian Economy (200 BC-AD 200), Cambridge

Müller, C. 2002: 'Les Italiens en Béotie du IIe siècle av. J.-C. au Ier siècle apr. J.-C.', in Müller and Hasenohr 2002, 89-100

Müller, C., and Hasenohr, C. (eds) 2002: Les Italiens dans le monde grec (IIe siècle av. J.-C.-Ier siècle ap. J.-C.). Circulation, activités, intégration, BCH Suppl. 4I, Athens/Paris

Nicolet, C. I966: L'Ordre équestre à l'époque républicaine (3 I 2-43 av. J.-C.), Tome I. Définitions juridiques et structures sociales, BEFAR 207, Paris

Niskanen, J. P. 2009: 'A shift in animal species used for food from the early Iron Age to the Roman period', in Forsén 2009, I 45-54 
Panella, C. 20Iо: 'Rome, il suburbio e l'Italia in età medio- e tardo-repubblicano: cultura materiale, territori, economie', Facta. A Journal of Roman Material Culture Studies, I I-I 23

Papaioannou, M. 2ого: 'East meets West: the pottery evidence from Abdera', Bolletino di Archeologia Online I, 53-65

Parker, A. J. I992: Ancient Shipwrecks of the Mediterranean and the Roman Provinces, BAR International Series 580 , Oxford

Paton, W., and Hicks, E. I891: The Inscriptions of Cos, Oxford

Pesavento Mattioli, S. 2005: 'Le anfore da allume. L'apporto di Padova. Bilancio e prospettive', in Borgard et al. $2005, \mathrm{I} 77-85$

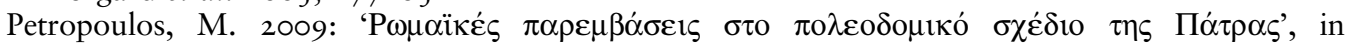
E. Carando and A. G. Benvenuti (eds), Patrasso colonia di Augusto e le trasformazioni culturali, politiche ed economiche della provincia di Acaia agli inizi dell'età imperiale romana, Tripodes 8, Athens, 39-77

Photos-Jones, E., Hall, A. J., and Atkinson, J. A. I999: 'The Aghia Kyriaki, Melos Survey: prospecting for the elusive earths in the Roman period in the Aegean', Annual of the British School at Athens 94, 377-4I3

Picon, M. 200I: 'Amphores Richborough 527 d'origine mélienne: amphores à alun de l'île de Mélos, Grèce', Société Française d'Étude de la Céramique Antique en Gaule (SFECAG), 393-97

Pleket, H. W. I988: 'Greek epigraphy and comparative ancient history: two case studies', Epigraphica Anatolica I 2, 25-37

Prag, J. 20I6: 'Antiquae sunt istae leges et mortuae: the plebiscitum Claudianum and associated laws', MEFRA I28.I, available online from <https://mefra.revues.org/3202>

Purcell, N. I995: 'The Roman villa and the landscape of production', in T. J. Cornell and K. Lomas (eds), Urban Society in Roman Italy, London, I 5 I-79

Purcell, N. 2005: 'Romans in the Roman world', in K. Galinsky (ed.), The Cambridge Companion to the Age of Augustus, Cambridge, 85-I05

Raptopoulos, S. 2005: 'Les producteurs d'alun de Milo: une histoire de patrons et d'ouvriers', in Borgard et al. 2005 , I 7 I-75

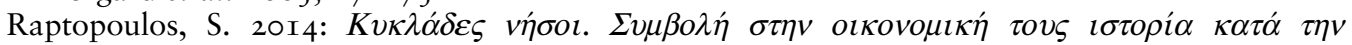

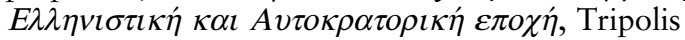

Rauh, N. K. I999: 'Rhodes, Rome, and the Eastern Mediterranean wine trade, I66-88 BC', in V. Gabrielsen, P. Bilde and T. Engberg Pedersen (eds), Hellenistic Rhodes. Politics, Culture, and Society, Aarhus, I62-86

Rawson, E. 1975: 'Architecture and sculpture: the activities of the Cossutti', Papers of the British School at Rome 43, 36-47

Rawson, E. I976: 'The Ciceronian aristocracy and its properties', in M. Finley (ed.), Studies in Roman Property, Cambridge, 85-102

Rawson, E. I994: 'Caesar: civil war and dictatorship', in J. A. Crook, A. Lintott and E. Rawson (eds), The Cambridge Ancient History. Vol. 9: The Last Age of the Roman Republic, I46-43 BC, Cambridge, 424-67

Reinders, H., and Prummel, W. I998: 'Transhumance in Hellenistic Thessaly', Environmental Archaeology 3, 8I-95

Renfrew, C., and Wagstaff, J. M. (eds) I982: An Island Polity: The Archaeology of Exploitation in Melos, Cambridge

Rizakis, A. D. I996: 'Les colonies romaines des côtes occidentales grecques. Populations et territoires', Dialogues d'Histoire Ancienne 22.I, 255-324

Rizakis, A. D. 2002: 'L'émigration romaine en Macédoine et la communauté marchande de Thessalonique: perspectives économiques et sociales', in Müller and Hasenohr 2002, I09-32

Roussel, P. [I916] I987: Délos, colonie athénienne (réimpression augmentée de compléments bibliographiques et de concordances épigraphiques), BEFAR I I I, Paris

Rousset, D. 2004: 'La cité et son territoire dans la province d'Achaïe et la notion de "Grèce romaine", Annales, Histoire, Science Sociales 59.2, 363-83

Säflund, M.-L. I980: Labraunda. Swedish Excavations and Researches II, 2. Stamped Amphora Handles, Lund

Sartre, M. I995: L'Asie Mineure et l'Anatolie d'Alexandre à Dioclétien (IVe s. av. J.-C.-IIIe s. ap. J.-C.), Paris

Scheidel, W., Morris, I., and Saller, R. P. (eds) 2007: The Cambridge Economic History of the Greco-Roman World, Cambridge 
Schulz, F. I942: 'Roman registers of births and birth certificates', Journal of Roman Studies 32, $78-9 \mathrm{I}$

Schulz, F. I943: 'Roman registers of births and birth certificates: Part II', Journal of Roman Studies $33,55-64$

Sestieri, P. C. I943: Nëshkrime latine të Shqipnís (= Iscrizioni Latine d'Albania), Tirana

Shackleton Bailey, D. R. (ed.) 1977: Cicero: Epistulae ad Familiares, Cambridge

Shatzman, I. 1975: Senatorial Wealth and Roman Politics, Brussels

Sherwin-White, S. 1978: Ancient Cos. An Historical Study from the Dorian Settlement to the Imperial Period, Hypomnemata, Göttingen

Shpuza, S. 20I I: 'L'espace rural illyrico-épirote. Contribution à l'étude de l'occupation du territoire et de l'économie à l'époque romaine', in P. Cabanes (ed.), L'Illyrie méridionale et l'Épire dans l'Antiquité. V, Paris, 607-16

Shpuza, S. 20I6: La Romanisation de l'Illyrie méridionale et de la Chaônie, CEFR 5I3, Rome

Skutsch, O. (ed.) I985: The Annals of Quintus Ennius, Oxford

Syme, R. I961: 'Who was Vedius Pollio?', Journal of Roman Studies 5 I, 23-30

Tartaron, T. F. 2004: Bronze Age Landscape and Society in Southern Epirus, Greece, Oxford

Tchernia, A. I986: Le Vin de l'Italie romaine. Essai d'histoire économique d'après les amphores, BEFAR 26I, Rome

Thonemann, P. 2010: 'The women of Akmoneia', Journal of Roman Studies 100, 163-78

Thonemann, P. 20I I: The Maeander Valley. A Historical Geography from Antiquity to Byzantium, Cambridge

Thonemann, P. 2013: 'Phrygia: an anarchist history (950 BC-AD I00)', in P. Thonemann (ed.), Roman Phrygia: Culture and Society, Cambridge, I-40

Tran, N. 20I4: 'Les hommes d'affaires romains et l'expansion de l'Empire (70 av. J.-C.-73 apr. J.-C.)', Pallas 96, I I 6-26

Verboven, K. 2007: 'Ce que negotiari et ses dérivés veulent dire', in J. Andreau and V. Chankowski (eds), Vocabulaire et expression de l'économie dans le monde antique, Bordeaux, 89-I I 8

Wallace-Hadrill, A. 2008: Rome's Cultural Revolution, Cambridge/New York

Wilson, A. J. N. 1966: Emigration from Italy in the Republican Age of Rome, Manchester

Wiseman, J., and Zachos, K. (eds) 2003: Landscape Archaeology in Southern Epirus, Greece. I, Hesperia Supplement 32, Princeton

Zaccaria, C. I989: 'Personaggi menzionati sui bolli dell'Italia nordorientale', in Amphores romaines et histoire économique. Dix ans de recherches, CEFR II4, Rome, 469-88

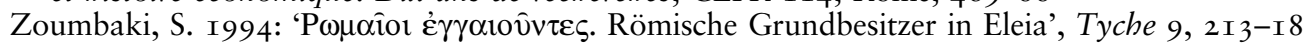

Zoumbaki, S. I998-99: 'Die Niederlassung römischer Geschäftsleute in der Peloponnes', Tekmeria 4, I I $2-76$

Zoumbaki, S. 20I 2: 'The exploitation of local resources of Western Greece by Roman entrepreneurs (3rd-Ist c. BC)', Revue Belge de Philologie et d'Histoire 90, 77-92

Zoumbaki, S. 20I3: 'In the search of the Horn of Plenty: Roman entrepreneurs in the agricultural economy of the province of Achaia', in A. D. Rizakis and I. P. Touratsoglou (eds), Villae Rusticae. Family and Market-Oriented Farms in Greece under Roman Rule, ME 68, Athens, 52-73

Zoumbaki, S. 20I4a: “"At the mercy of waves and storms...”: Roman and Italiote traders and settlers in the Cyclades', in G. Bonnin and E. Le Quéré (eds), Pouvoirs, îles et mer. Formes et modalités de l'hégémonie dans les Cyclades antiques (VIIe s. a.C.-IIIe s. p.C.), Scripta Antiqua 64, Bordeaux, 3 I $7-30$

Zoumbaki, S. 20I4b: 'More negotium than otium. Social and economic aspects of leisure in the villas of the Roman province of Achaia', in O. Devillers (ed.), Neronia IX. La villégiature dans le monde romain de Tibère à Hadrien, Scripta Antiqua 62, Bordeaux, I 85-94

Zoumbaki, S. 20I7: 'Where East meets West: mobility between the two shores of the Adriatic and its impact on the economy and identity of the insular societies of the Ionian Sea in the late Hellenistic and Roman periods', in A. Kouremenos (ed.), Insularity and Identity in the Roman Mediterranean, Oxford 